\title{
Relationship between structural and functional aspects of microbial and macrofaunal communities in different areas of the North Sea
}

\author{
Ingrid Kröncke ${ }^{1, *}$, Thorsten Stoeck ${ }^{1}$, Gunther Wieking ${ }^{1}$, Ansa Palojärvi ${ }^{2}$ \\ ${ }^{1}$ Senckenberg Institute, Department for Marine Research, Südstrand 40, 26382 Wilhelmshaven, Germany \\ ${ }^{2}$ MTT Agrifood Research Finland, Soils and Environment, 31600 Jokioinen, Finland
}

\begin{abstract}
Spatial similarities of structural and functional (trophic) aspects of microbial and macrofaunal community patterns were studied in relation to sediment parameters in the German Bight, the Oyster Ground, the Dogger Bank, eastern North Sea, the Skagerrak, and northern Kattegat in May and September 1999 and 2000. Spatial patterns of microbial and macrofaunal communities were congruent. Differences in spatial distribution of communities were caused by utilisation of the different food sources available in the different areas. In the German Bight, the communities were correlated significantly with chlorophyll a ( $\mathrm{chl}$ a) concentrations in the sediments, an indicator of fresh nitrogenrich organic matter. In contrast, communities in the Skagerrak and Kattegat were correlated with total organic carbon (TOC) and mud concentrations, indicating the presence of more refractory organic matter for the microbial and macrofaunal organisms. For the communities in the Oyster Ground, the eastern North Sea and the Dogger Bank, no such significant correlations were found. The community in the Oyster Ground was characterised by the ophiurid Amphiura filiformis foraging on relatively refractory macrofloculate organic matter from the benthic boundary layer. Preferred substrates of the microbial communities in this area were macrofaunal excretion products. The Skagerrak and Kattegat stations were also characterised by the A. filiformis community, indicating lower food supply than in the German Bight. Although microbial community patterns were similar to those in the German Bight, lower chl a concentrations also suggested the presence of relatively refractory organic matter. Reflected by the dominance of sand-licking species, macrofaunal communities at the Dogger Bank and in parts of the eastern North Sea seem to rely on benthic primary production. Here, microbial communities were adapted to hydrodynamically induced stress, sediment disturbance and limited food supply. Our results revealed that in areas with high food supply such as the German Bight, no competition for food between microorganisms and macrofauna occurs. But in areas with less or limited food supply from the water column, macrofauna provides the microorganisms with organic matter or microorganisms utilise macrofaunal excretion products and are physiologically adapted to the exposed environment.
\end{abstract}

KEY WORDS: Microorganisms $\cdot$ Macrofauna $\cdot$ Community structure $\cdot$ Trophic relationships $\cdot$ Food availability $\cdot$ Phytopigments $\cdot$ North Sea

Resale or republication not permitted without written consent of the publisher

\section{INTRODUCTION}

Macrofaunal communities in the North Sea have been intensively studied since 1920 (see review by Kröncke \& Bergfeld 2003). The various macrofaunal communities occurring in different areas of the North
Sea have been described in numerous publications (e.g. Salzwedel et al. 1985, Kröncke 1992, Künitzer et al. 1992, E. Rachor \& P. Nehmer unpubl. data). In contrast, very little information is available on bacteria and microorganisms living in the North Sea benthic system (Billen et al. 1990). Van Duyl et al. (1993) and van Duyl 
\& Kop (1994) studied benthic bacterial biomass and production in sediments of different areas of the North Sea and found that both parameters were significantly related to pigment concentrations in sediments. Temperature and phytopigment concentration accounted for major percentages of seasonal and spatial variations in bacterial production. Upton et al. (1993) and Osinga et al. (1996) compared the benthic mineralisation rates of different sediment types in different areas of the southern North Sea. They found differences in oxygen uptake, sulphate reduction and bacterial production due to variability in carbon supply and hydrodynamics. Upton et al. (1993) stated that, on average, benthic mineralisation was equivalent to $17-45 \%$ of the total net primary production.

The relationship between structural and trophic aspects of microbial and macrofaunal communities has mainly been studied experimentally (Aller 1982, 1988, Alongi \& Hanson 1985, Alongi \& Tenore 1985, Sundbäck et al. 1990), in situ in the intertidal (Kristensen et al. 1985, Andersen \& Kristensen 1988, 1991, 1992, Kristensen 1988) or in the deep-sea (Rowe \& Deming 1985, Rowe et al. 1991, Rowe \& Pariente 1992, Rowe 1996, Kröncke et al. 2000), but not in the offshore North Sea. The experimental and intertidal studies revealed that bioturbation by macrofauna stimulates both the aerobic and anaerobic decomposition processes, causing benthic metabolism to increase 1.5 to 3 times in the presence of burrowing macrofauna. Regarding competition for food, Kristensen (2000) showed that the polychaete Nereis (Hediste) diversicolor competes with microorganisms for high-quality food and microbial activity generally decreases in the presence of the polychaete.

To obtain more insight into the relationship between microbial and macrofaunal communities, we studied microorganisms and macrofauna from the same box cores during 4 cruises in 1999 and 2000 in different areas of the North Sea (German Bight, the eastern North Sea, Dogger Bank, Skagerrak and northern Kattegat) (Stoeck \& Kröncke 2001, Stoeck et al. 2002, 2003 , present study). These areas were chosen because they are known to be different in terms of primary production, sedimentation rates and hydrodynamics (Eisma \& Kalf 1987, Kröncke \& Knust 1995, de Haas \& van Weering 1997, Puls et al. 1997).

The results on microbial communities of our interdisciplinary study have already been published (Stoeck \& Kröncke 2001, 2002, 2003). In our 2001 study we emphasized the influence of particle mixing on verticle profiles of chl $a$ and bacterial biomass. Our 2002 study focused on phospholid fatty acid profiles at depositional and non-depositional sites, and our 2003 study examined functional profiles of microbial communities in relation to organic substrates.
In this paper, we compare macrofaunal and microbial data sets, with special emphasis on the following: (1) Is microbial and macrofaunal spatial distribution congruent? (2) What role does the food availability play on microbial and macrofaunal communities? (3) Do microbial and macrofaunal communities compete for food?

\section{MATERIALS AND METHODS}

Study sites. The study sites in the German Bight (Stns TS 2 to 5), the Oyster Ground (Stns TS 6 to 8) and the Dogger Bank area (Stns TS9, DB9, DB11 and DB12) were sampled in May and September 1999; those in the eastern North Sea (Stns EN1 to EN5), the Skagerrak (Stn SK) and northern Kattegat (Stn KT) in May and September 2000 (Table 1, Fig. 1).

Sampling. Samples were taken during cruises with RV 'Senckenberg' using a $0.1 \mathrm{~m}^{2}$ USNEL box corer equipped with a closing lid to prevent any disturbance of the sediment surface. Three cores per station were sub-sampled for macrofauna, microbes and sediment analyses.

For microorganisms and sediment analyses 5 PVC tubes ( $40 \mathrm{~cm}$ long, $5 \mathrm{~cm}$ inner diameter) were taken per core. All cores were sliced at 2,5 and $10 \mathrm{~cm}$. Only data

Table 1. Coordinates, depth, bottom-water temperature and salinity at study sites (Fig. 1) in May and September 1999 and 2000

\begin{tabular}{|c|c|c|c|c|c|}
\hline $\begin{array}{l}\text { Study } \\
\text { site }\end{array}$ & $\begin{array}{l}\text { Latitude } \\
\text { (N) }\end{array}$ & $\begin{array}{l}\text { Longitude } \\
\text { (E) }\end{array}$ & $\begin{array}{l}\text { Depth } \\
\text { (m) }\end{array}$ & $\begin{array}{l}\text { Temp }\left({ }^{\circ} \mathrm{C}\right) \\
\text { May/Sep }\end{array}$ & $\begin{array}{c}\text { Salinity } \\
\text { May/Sep }\end{array}$ \\
\hline \multicolumn{6}{|c|}{ German Bight } \\
\hline TS2 & $54^{\circ} 02^{\prime}$ & $008^{\circ} 02^{\prime}$ & 25 & 11.6/18.5 & $32.6 / 33.2$ \\
\hline TS4 & $54^{\circ} 00^{\prime}$ & $007^{\circ} 50^{\prime}$ & 34 & 11.1/18.5 & $33.8 / 34.4$ \\
\hline TS5 & $54^{\circ} 06^{\prime}$ & $007^{\circ} 24^{\prime}$ & 33 & 11.6/18.1 & $34.2 / 34.1$ \\
\hline TS6 & $54^{\circ} 25^{\prime}$ & $006^{\circ} 16^{\prime}$ & 37 & $11.4 / 17.9$ & $34.6 / 34.9$ \\
\hline TS7 & $54^{\circ} 49^{\prime}$ & $005^{\circ} 35^{\prime}$ & 41 & $10.7 / 16.9$ & $35.1 / 36.5$ \\
\hline TS8 & $55^{\circ} 06^{\prime}$ & $005^{\circ} 01^{\prime}$ & 37 & $9.7 / 13.8$ & $35.1 / 35.8$ \\
\hline TS9 & $55^{\circ} 29^{\prime}$ & $004^{\circ} 10^{\prime}$ & 29 & $10.6 / 15.0$ & $35.3 / 35.7$ \\
\hline \multicolumn{6}{|c|}{ Dogger Bank } \\
\hline DB9 & $55^{\circ} 33^{\prime}$ & $002^{\circ} 59^{\prime}$ & 42 & $10.2 / 12.2$ & $36.2 / 36.3$ \\
\hline DB11 & $55^{\circ} 01^{\prime}$ & $003^{\circ} 00^{\prime}$ & 23 & $12.6 / 16.7$ & $36.3 / 35.4$ \\
\hline DB12 & $54^{\circ} 37^{\prime}$ & $003^{\circ} 00^{\prime}$ & 34 & $11.7 / 14.9$ & $35.9 / 36.5$ \\
\hline \multicolumn{6}{|c|}{ Eastern North Sea } \\
\hline EN1 & $54^{\circ} 40^{\prime}$ & $007^{\circ} 40^{\prime}$ & 19 & $12.2 / 16.8$ & $33.7 / 32.3$ \\
\hline EN2 & $55^{\circ} 00^{\prime}$ & $007^{\circ} 20^{\prime}$ & 28 & $11.2 / 16.5$ & $34.8 / 33.6$ \\
\hline EN3 & $55^{\circ} 40^{\prime}$ & $007^{\circ} 00^{\prime}$ & 30 & 10.5/16.2 & $35.2 / 34.8$ \\
\hline EN4 & $56^{\circ} 00^{\prime}$ & $006^{\circ} 20^{\prime}$ & 44 & $9.6 / 14.8$ & $35.4 / 35.2$ \\
\hline EN5 & $56^{\circ} 30^{\prime}$ & $007^{\circ} 20^{\prime}$ & 35 & $10.2 / 15.3$ & $35.8 / 34.8$ \\
\hline \multicolumn{6}{|c|}{ Skagerrak (SK) } \\
\hline & $57^{\circ} 49^{\prime}$ & $009^{\circ} 10^{\prime}$ & 140 & $10.0 / 10.8$ & $32.5 / 35.8$ \\
\hline \multicolumn{6}{|c|}{ Kattegat (KT) } \\
\hline & $57^{\circ} 38^{\prime}$ & $010^{\circ} 58^{\prime}$ & 28 & $11.8 / 15.8$ & $22.0 / 23.0$ \\
\hline
\end{tabular}


from the surface sediments are presented here (for details of sampling see Stoeck \& Kröncke 2001). All subsamples taken at each station were pooled and mixed to prevent selective sampling. Mixed samples were frozen at $-20^{\circ} \mathrm{C}$.

Macrofauna samples were taken using $10 \mathrm{~cm}$ diameter plastic tubes; 2 to 3 tubes were taken per core. All cores were sliced at 2, 5 and $10 \mathrm{~cm}$, but abundances of all depths were pooled because the main percentage of fauna was found in the upper $2 \mathrm{~cm}$. Thus, values are related to a sample area of $10 \mathrm{~cm}$ diameter. Samples were sieved through $0.5 \mathrm{~mm}$ sized mesh and the animals retained were fixed in $4 \%$ buffered formalin.

Sample treatment. The mud concentration $(<63 \mu \mathrm{m})$ at each station was analysed using the laser particle sizer 'Analysette 22 Economy' (Fritsch) as described in detail by Stoeck et al. (2000).

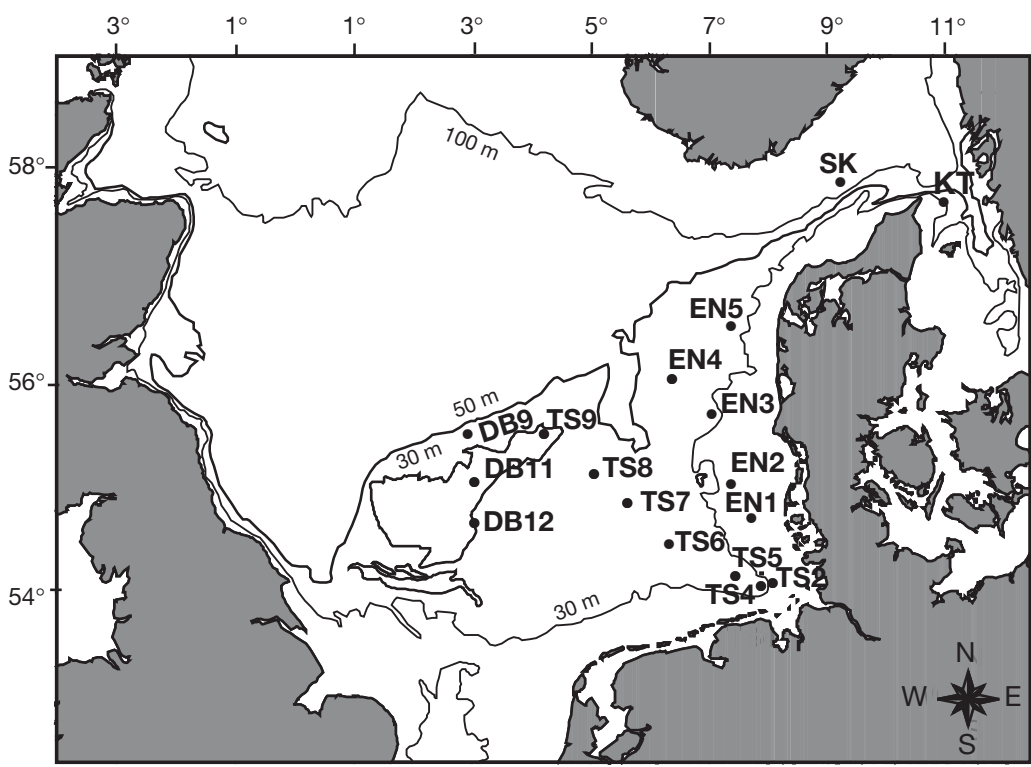

Fig. 1. Map with stations in the German Bight and Oyster Ground (TS), at the Dogger Bank (DB), in the eastern North Sea (EN) and in the Skagerrak (SK) and Kattegat (KT)
Analyses of sediment total organic car-

bon (TOC) and total nitrogen were determined on freeze-dried samples that had been finely powdered and homogenised. An aliquot of 10 to $30 \mathrm{mg}$ was combusted at $1010^{\circ} \mathrm{C}$ in an Heraeus $\mathrm{C} / \mathrm{N}$ analyser following acidification with concentrated $\mathrm{HCl}$ in a desiccator to remove inorganic carbonates (Hedges \& Stern 1984).

The redox gradients of 3 undisturbed sediment cores were measured on board ship using a GAT Ionode IH30 (GAT) together with a Portamess 651-2 Microprocessor (Knick).

Chl a was extracted from $5 \mathrm{~g}$ sediment with $5 \mathrm{ml}$ $90 \%$ acetone. After incubation of the suspension for $1 \mathrm{~h}$ at $4^{\circ} \mathrm{C}$ in darkness it was mixed for $1 \mathrm{~min}$, followed by ultrasonication in a water bath for 3 min at medium power. To remove particles the suspension was centrifuged for $25 \mathrm{~min}$ at $1745 \times g$ at $0^{\circ} \mathrm{C}$. Chl a was analysed in the supernatant by high performance liquid chromatography (HPLC) as described by Wallerstein \& Liebezeit (1999).

Total bacterial counts (TBC) were determined after staining with the fluorescent dye bisbenzimid H33342 (Sigma) according to the method of Stoeck \& Albers (2000). Briefly, immediately after sampling, fresh sediment $(0.2 \mathrm{~g})$ was mixed with $5 \mathrm{ml}$ sterile seawater containing EDTA and formol to a final concentration of $5 \mathrm{mM}$ and $3.7 \%$, respectively, and stored in darkness at $4^{\circ} \mathrm{C}$ until further processing. In the laboratory, the sample was ultrasonicated for $30 \mathrm{~s}$ with an Ultrasonic Processor (Soniprep 150, MSE) and the suspension was mixed for $1 \mathrm{~min}$. The procedure of ultrasonication and mixing was repeated 3 times. Subsequently, the sus- pension was centrifuged at $500 \times g$ for $15 \mathrm{~min}$. A $5 \mathrm{ml}$ aliquot of the supernatant was stained with the fluorescent dye Hoechst 33342 (Sigma) for $90 \mathrm{~min}$ at $37^{\circ} \mathrm{C}$, and filtered on a black polycarbonate membrane filter (0.2 $\mu \mathrm{m}, 25 \mathrm{~mm}$, Costar). Blue-stained bacteria were counted with an epifluorescence microscope (Zeiss Axiophot) using an excitation of $395 \mathrm{~nm}$ and an emission of $420 \mathrm{~nm}$.

Microbial biomass and activity was determined as sediment DNA and RNA concentration, respectively, according to Stoeck et al. (1998). Because the cellular RNA concentration is significantly related to the metabolic activity of the respective cell(s), the cellular RNA concentration is considered to be a measure of microbial activity for single cells and cultures, as well as communities (Dortch et al. 1983, Frantzis et al. 1992, 1993). These analyses detect not only bacterial biomass and activity, but included also protists and small fauna. Nucleic acid measurements were performed using a high-performance liquid chromatography (HPLC) technique as described by Stoeck et al. (1998). A subsample of the homogenised sediment was frozen at $-20^{\circ} \mathrm{C}$ and freeze-dried. An aliquot of $0.2 \mathrm{~g}$ of the dried sediment (3 replicates) was transferred into $1 \mathrm{ml}$ of Tris- $\mathrm{HCl}$ buffer containing $0.2 \%$ sodium dodecyl sulphate and $0.4 \%$ EDTA. The mixture was sonicated (Soniprep $150 \mathrm{MSE}$ ) 3 times for $10 \mathrm{~s}$ at $1 \mathrm{~min}$ intervals. After sonication, the samples were centrifuged for $5 \mathrm{~min}$ at $3000 \times \mathrm{g}$. To remove particulate material the supernatant was filtered over a $0.45 \mu \mathrm{m}$ pore size cellulose acetate filter. In accordance with Copella et al. (1987), we used a urea buffer with a $\mathrm{KCl}$ gradient for 
HPLC analysis. DNA-C, i.e. the carbon biomass on the basis of DNA, was calculated using a C:DNA ratio of 83 (Holm-Hansen et al. 1968).

Phospholipid fatty acids (PLFA) were analysed at certain stations only. Until now, only few PLFAs have been identified as markers for certain bacteria or microbial groups (described in detail by Stoeck et al. 2002). Because analysis of phospholipid fatty acids is time- and cost-intense, samples for a reduced number of stations were analysed: TS2, TS7, DB9, DB11, DB12 in May and September 1999; EN5, SK, KT in May and September 2000. PLFA analyses were performed according to Frostegård et al. (1993) and Palojärvi et al. (1997), with slight modifications. Lipid extractions and fractionations were carried out from $8 \mathrm{~g}$ (samples from Stns GB, KT and $\mathrm{SK}$ ) or $16 \mathrm{~g}$ (samples from all other stations) of freezedried sediment (for details see Stoeck et al. 2002). The nomenclature used to describe fatty acids was as follows. The number before the colon indicates the number of carbon atoms in the fatty acid, the number after the colon the degree of unsaturation (= the number of carbon carbon double bonds). The position of the first double bond is indicated by the number of carbon units from the methyl (or aliphatic; ' $\omega$ ') end of the molecule of the monounsaturated fatty acid (MUFA). In the polyunsaturated fatty acid (PUFA) ' $\omega$ ' is followed by the position of the first double bond from the terminal methyl end of the molecule. When the exact position of the double bond was unknown, the ' $\omega$ ' was omitted. The suffixes ' $C$ ' and
' $t$ ' indicate cis and trans geometry. The prefixes ' $i$ ' and ' $a$ ' refer to iso and anteiso branching; ' $b r$ ' indicates unknown methyl branching position. Other methyl branching is indicated by the position of the additional methyl carbon from the carboxyl end followed by ' $\mathrm{Me}$ ' (10Me18:0). The number before the prefix ' $\mathrm{OH}^{\prime}$ indicates the position of a hydroxy group from the carboxyl end (3-OH14:0). Cyclopropane fatty acids are designated by the prefix ' $c y$ '.

Macrofaunal organisms were identified in the laboratory, to species level where possible. Data for subsamples of each core and station were summed and then calculated $\mathrm{m}^{-2}$. Biomass was determined as wet weight, which was converted into Ash Free Dry Weight (AFDW) using conversion factors on a faunal class level given by Rumohr et al. (1987) and Ricciardi \& Bourget (1998). Feeding modes were determined according to Fauchald \& Jumars (1979), Lincoln (1979), Hartmann-Schröder (1996) and Dauwe et al. (1998).

Statistics. We used the PRIMER v5 program package to perform cluster analyses of macrofaunal and microbial (PLFA) abundance data to reveal similarities between stations (Clarke \& Warwick 1994). Similarities were calculated using the Bray-Curtis coefficient. Square-root transformation was used for faunal abundance, none for PLFAs. The average group-linkage method was used to calculate dendrograms. Similarity percentage analysis (SIMPER) was used to analyse dominance of species.

Table 2. Sediment, microbial and macrofaunal parameters at stations in different areas of North Sea in May and September 1999 and 2000. Original data of sediment contents and microbial parameters in Stoeck \& Kröncke (2001) and Stoeck et al. (2002) were converted to volume-specific concentrations using equations of Delafontaine et al. (1996) and Flemming \& Delafontaine (2000). TOC: total organic carbon; Eh: redox potential; Chl a: chlorophyll $a_{i}$ TBC: total bacteria counts; DNA-C: microbial biomass; PLFA: phospholipid fatty acids; station abbreviations as in Table 1 ; -: no data

\begin{tabular}{|c|c|c|c|c|c|c|c|c|c|c|c|c|}
\hline \multirow[t]{2}{*}{ Stn } & \multicolumn{2}{|c|}{$\underset{\left(\mathrm{kg} \mathrm{m}^{-2}\right)}{\operatorname{Mud}}$} & \multicolumn{2}{|c|}{$\begin{array}{c}\text { TOC } \\
\left(\mathrm{g} \mathrm{m}^{-2}\right)\end{array}$} & \multicolumn{2}{|c|}{$\begin{array}{c}\mathrm{Eh} \\
(\mathrm{mV})\end{array}$} & \multicolumn{2}{|c|}{$\begin{array}{c}\mathrm{Chl} \mathrm{a} \\
\left(\mathrm{mg} \mathrm{m}^{-2}\right)\end{array}$} & \multicolumn{2}{|c|}{$\begin{array}{c}\text { TBC- } \times \\
10^{14} \mathrm{~m}^{-2}\end{array}$} & \multicolumn{2}{|c|}{$\begin{array}{l}\text { DNA-C } \\
\left(\mathrm{g} \mathrm{m}^{-2}\right)\end{array}$} \\
\hline & May & Sep & May & Sep & May & Sep & May & Sep & May & Sep & May & Sep \\
\hline TS2 & 13.65 & 14.55 & 431.21 & 518.03 & -115 & -170 & 61.95 & 29.74 & 2.87 & 1.89 & 209.13 & 54.55 \\
\hline TS4 & 8.9 & 9.73 & 241.63 & 271.62 & -53 & -122 & 69.40 & 31.56 & 3.09 & 1.46 & 48.78 & 103.46 \\
\hline TS5 & 4.5 & 5.72 & 156.46 & 178.91 & -46 & 0 & 55.87 & 28.61 & 2.53 & 1.18 & 52.84 & 147.34 \\
\hline TS6 & 5.68 & 6.39 & 178.13 & 192.18 & 192 & 100 & 28.11 & 28.18 & 2.94 & 0.96 & 38.97 & 69.69 \\
\hline TS7 & 4.58 & 5.16 & 157.87 & 168.39 & 193 & -106 & 30.27 & 30.39 & 1.92 & 1.17 & 30.95 & 109.28 \\
\hline TS8 & 0.92 & 0.81 & 101.98 & 100.49 & 193 & 180 & 28.08 & 32.04 & 1.51 & 1.02 & 48.71 & 72.95 \\
\hline TS9 & 0.24 & 0.31 & 93.35 & 94.21 & 145 & 274 & 45.94 & 33.53 & 2.71 & 2.59 & 42.57 & 52.32 \\
\hline DB9 & 0.31 & 0.20 & 94.29 & 92.96 & 7 & 60 & 26.07 & 33.18 & 2.2 & 0.58 & 32.85 & 52.9 \\
\hline DB11 & 0.29 & 0.28 & 93.98 & 93.9 & 186 & 179 & 21.02 & 43.74 & 1.31 & 0.56 & 42.34 & 56.49 \\
\hline DB12 & 1.48 & 1.63 & 109.36 & 111.48 & 267 & 227 & 30.55 & 36.67 & 1.23 & 1.43 & 56.56 & 89.42 \\
\hline EN1 & 2.05 & 1.71 & 117.53 & 112.58 & 126 & 180 & 32.26 & 18.64 & 0.82 & 0.96 & 30.21 & 42.38 \\
\hline EN2 & 7.1 & 6.8 & 206.94 & 200.5 & 230 & 16 & 26.6 & 31.51 & 0.67 & 0.61 & 57.40 & 107.30 \\
\hline EN3 & - & 4.88 & - & 163.29 & - & 22 & - & 24.83 & - & 0.64 & - & 72.96 \\
\hline EN4 & 10.57 & 4.53 & 296.74 & 157.09 & -14 & -65 & 29.09 & 32.06 & 0.68 & 0.99 & 28.44 & 52.22 \\
\hline EN5 & 0.85 & 1.81 & 101.04 & 113.99 & 215 & 105 & 32.43 & 28.85 & 0.61 & 0.31 & 23.82 & 39.73 \\
\hline SK & 14.42 & 14.54 & 499.27 & 516.78 & -16 & -31 & 20.94 & 21.17 & 1.43 & 1.25 & 72.77 & 57.87 \\
\hline KT & 11.04 & 12.56 & 873.72 & 802.99 & -33 & -91 & 11.57 & 10.38 & 0.9 & 0.88 & 50.83 & 49.62 \\
\hline
\end{tabular}


A canonical correspondence analysis (CCA, Microcomputer Power) was applied to reveal relationships between the macrofaunal and microbial community patterns and sediment-bulk parameters. This ordination technique, developed for community analysis (ter Braak 1986), differs from other 2-step ordination techniques in that CCA allows direct analysis of the effect of specific environmental variables because ordination axes are constrained to be linear combinations of environmental variables (ter Braak \& Verdonschot 1995). We used a Monte Carlo permutation test (ter Braak \& Smilauer 1998) to check the statistical validity of the association between environmental variables and variance in the community pattern.

\section{RESULTS}

\section{Mud, total organic carbon (TOC), Eh and chl a}

Mud, TOC and chlorophyll a concentrations in the southern North Sea were highest in the inner German Bight and decreased towards the Oyster Ground to the Dogger Bank (Table 2). At Dogger Bank Stn DB12, TOC and chl a concentrations were similar to those at the eastern North Sea stations EN2 and EN5, but mud concentrations were lower. In the eastern North Sea the lowest mud and TOC concentrations were found at Stns EN1 and EN5, but chl a concentrations were similar to those at Stns EN2 to EN4. At the deep Skagerrak station (SK) mud and TOC concentrations were similar to those in the inner German Bight Stn TS2, but TOC and chl a concentrations were lower. The Kattegat station had the highest TOC concentration of all sites, but the lowest chl a concentrations. In general, no significant differences in mud and TOC concentrations occurred between May and September. Chl a concentrations were higher in May than in September in the inner German Bight and half of the eastern North Sea and in the Kattegat and vice versa in September at the Dogger Bank stations. Negative Eh values were only found in the inner German Bight, at Stn EN4 and at the Skagerrak and Kattegat stations.

\section{Total bacterial counts (TBC) and microbial biomass (DNA-C)}

The bacterial abundance (TBC) and microbial biomass patterns were similar to those of the sediment parameter (Table 2). In the North Sea, the highest TBCs were found in the inner German Bight and decreased towards the Dogger Bank. Lowest counts were found at the eastern North Sea stations. Maximum concentrations of microbial biomass were also found in the inner German Bight and the Skagerrak and Kattegat stations, but concentrations at the remaining stations were fairly homogeneously distributed. TBCs and microbial biomass at the Skagerrak and Kattegat stations were similar to those in the eastern and Dogger Bank stations. TBCs were generally higher in May, microbial biomass was generally higher in September.

Table 2 (continued)

\begin{tabular}{|c|c|c|c|c|c|c|c|c|c|c|c|}
\hline \multirow{2}{*}{$\begin{array}{l}\text { RNA } \\
\left(\mathrm{g} \mathrm{m}^{-2}\right) \\
\text { May }\end{array}$} & \multirow[b]{2}{*}{ Sep } & \multicolumn{2}{|c|}{ 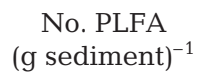 } & \multicolumn{2}{|c|}{$\begin{array}{l}\text { PLFA biomass } \\
\left(\mathrm{mmol} \mathrm{m}^{-2}\right)\end{array}$} & \multicolumn{4}{|c|}{$\begin{array}{l}\text { Species }\left(\text { no. } 0.04 \mathrm{~m}^{-2} \text { ) Abundance (ind. } \mathrm{m}^{-2} \text { ) }\right.\end{array}$} & \multicolumn{2}{|c|}{ Biomass $\left(\mathrm{gC} \mathrm{m}^{-2}\right)$} \\
\hline & & May & Sep & May & Sep & May & Sep & May & Sep & May & Sep \\
\hline 0.69 & 1.27 & 34 & 36 & 1.76 & 2.11 & 35 & 46 & 7770 & 14476 & 4.92 & 8.69 \\
\hline 0.98 & 0.76 & - & - & - & - & 40 & 49 & 9380 & 6258 & 7.31 & 4.54 \\
\hline 0.47 & 0.99 & - & - & - & - & 13 & 24 & 2898 & 3885 & 0.1 & 0.65 \\
\hline 0.33 & 0.39 & 26 & 25 & 0.69 & 1.00 & 39 & 31 & 2408 & 3486 & 5 & 0.53 \\
\hline 0.64 & 0.62 & - & - & - & - & 32 & 40 & 2254 & 2128 & 6.12 & 6.83 \\
\hline 0.26 & 0.35 & - & - & - & - & 29 & 34 & 3066 & 4214 & 22 & 8.58 \\
\hline 0.39 & 0.14 & 27 & 29 & 0.74 & 1.04 & 21 & 40 & 2226 & 3122 & 0.15 & 1.39 \\
\hline 0.15 & 0.26 & 22 & 22 & 0.44 & 0.78 & 16 & 41 & 2814 & 3262 & 0.25 & 0.75 \\
\hline 0.27 & 0.25 & 22 & 25 & 0.44 & 0.68 & 29 & 46 & 13356 & 3808 & 4.66 & 0.46 \\
\hline 0.37 & 0.5 & 24 & 27 & 0.96 & 1.56 & 29 & 37 & 1932 & 2562 & 4.73 & 1.54 \\
\hline 0.16 & 0.3 & - & - & - & - & 29 & 39 & 1484 & 5264 & 1.2 & 2.13 \\
\hline 0.52 & 0.78 & - & - & - & - & 18 & 32 & 504 & 44478 & 0.49 & 9.97 \\
\hline- & 0.64 & - & - & - & - & - & 39 & - & 8085 & - & 0.69 \\
\hline 0.2 & 0.35 & - & - & - & - & 29 & 31 & 4774 & 6237 & 0.82 & 1.02 \\
\hline 0.17 & 0.34 & 27 & 22 & 0.76 & 0.51 & 23 & 28 & 2884 & 3759 & 11.02 & 1.77 \\
\hline 0.54 & 0.55 & 34 & 33 & 1.31 & 1.17 & 33 & 24 & 5096 & 9310 & 1.33 & 1.87 \\
\hline 0.37 & 0.32 & 36 & 35 & 1.14 & 1.07 & 49 & 42 & 13622 & 4816 & 1.53 & 9.91 \\
\hline
\end{tabular}


Table 3. Significant correlations $\left({ }^{*}: 5 \%\right.$ level) between microbial, macrofaunal and sediment-bulk parameters. Abbreviations as in Table 2

\begin{tabular}{|lcccc|}
\hline & TBC & RNA & DNA & $\begin{array}{c}\text { Macrofaunal } \\
\text { abundance }\end{array}$ \\
\hline May & & & & \\
Chl $a$ & $*$ & $*$ & & \\
TOC & & $*$ & $*$ & $*$ \\
Mud & & $*$ & $*$ & $*$ \\
September & & & & \\
Chl a & & & & \\
TOC & & $*$ & & \\
Mud & & $*$ & & \\
\hline
\end{tabular}

\section{Microbial activity (RNA)}

Microbial activity did not follow the patterns of sediment parameters, TBC and DNAC. Highest microbial activity occurred at the German Bight and the eastern North Sea stations EN2 and EN3 (Table 2). Values in the Oyster Ground were similar to those measured in sediments from the eastern North Sea (EN1, EN4 and EN5) as well as the Skagerrak and Kattegat stations.

\section{Correlations between sediment, bacterial and microbial bulk parameters}

In May, TBCs and microbial activity correlated significantly with chl a concentrations, while microbial activity and biomass were also both correlated with TOC and mud concentrations. Macrofaunal abundance correlated with mud and TOC concentrations. In September, only microbial activity was significantly correlated with mud concentrations (Table 3).

\section{Abundance and biomass of phospholipid fatty acids (PLFAs)}

We identified 36 PLFAs in North Sea sediments (Stoeck et al. 2002). The majority is considered to be of bacterial origin, because fatty acids in the range of $\mathrm{C}_{12}$ to $\mathrm{C}_{19}$ are known to be characteristic of bacteria (Lechevalier 1977). Additionally, fatty acids were detected which are known to be present in protists and microeukaryotes. More than 30 different fatty acids and the highest
PLFA biomass were found in depositional areas such as the German Bight, Skagerrak and Kattegat. Hardly any seasonal differences were found in PLFA numbers, but biomass was higher in September at the southern stations (Table 2).

\section{Microbial community structure = PLFA composition}

Cluster analysis revealed high spatial similarities (>80\%) of PLFA distribution at the study sites (Fig. 2) in regard to total number (as well as in the relative proportion of single fatty acids published in detail by Stoeck et al. 2002). The Skagerrak, Kattegat and inner German Bight Stn TS2 appeared in 1 cluster in both May and September. Another cluster was observed for Stns TS7, DB12 and EN5 in May. In September, Stn EN5 joined the third cluster of stations (DB9, DB11 and TS9) from the more northern Dogger Bank area.

Saturated, monounsaturated (MUFA), polyunsaturated (PUFA), branched (br), cyclopropyl (cy) and
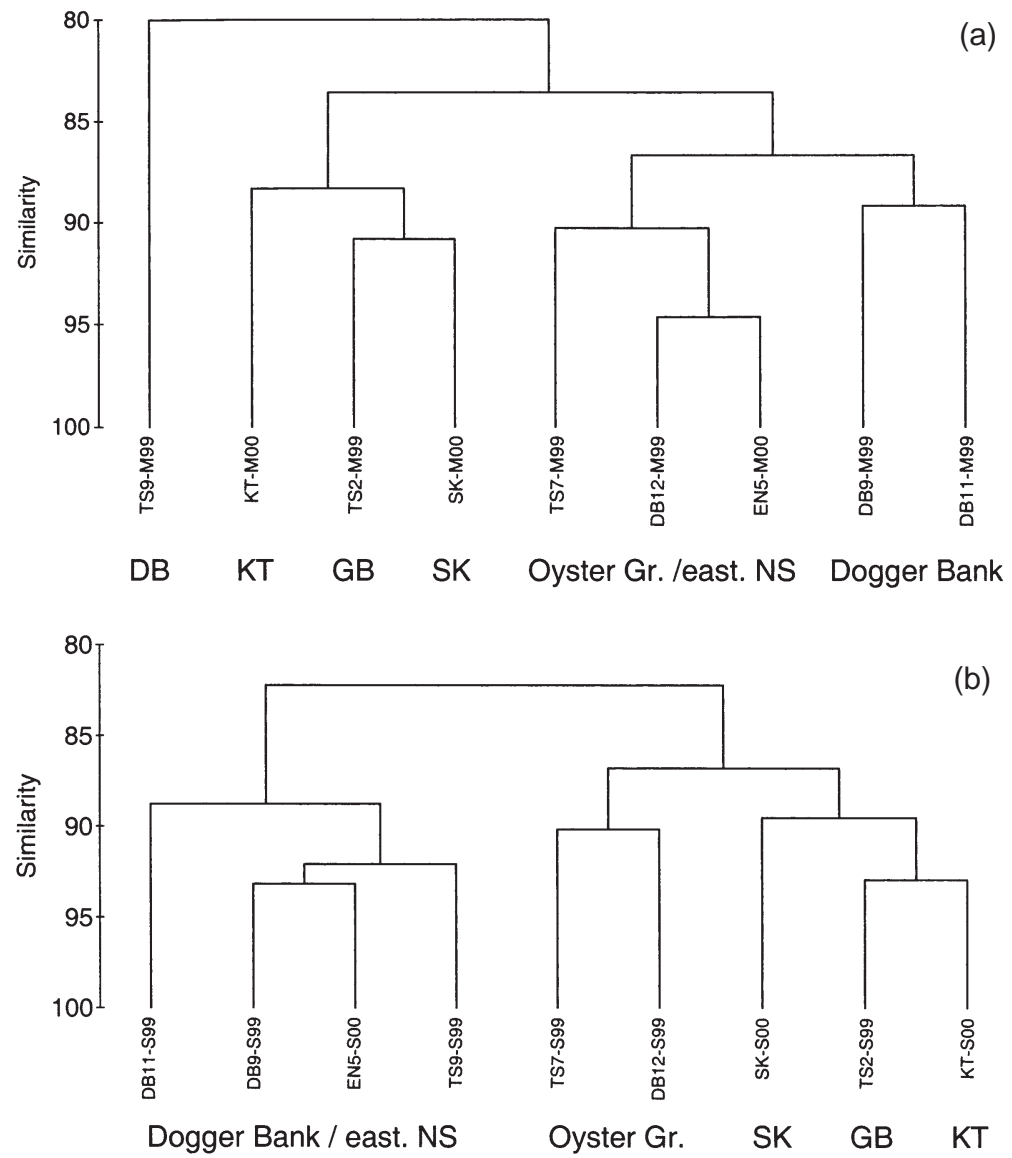

Fig. 2. Dendrograms for microbial communities (composition of PLFAs) in (a) May and September 1999 and 2000 (b) in the German Bight (GB), Oyster Ground, at the Dogger Bank (DB), in the eastern North Sea (EN) and in the Skagerrak (SK) and Kattegat (KT) 
hydroxy $(\mathrm{OH})$ fatty acids in the range of $\mathrm{C}_{12}$ to $\mathrm{C}_{24}$ were identified. The majority of PLFAs is considered to be of bacterial origin $\left(\mathrm{C}_{12}\right.$ to $\left.\mathrm{C}_{19}\right)$ and the major percentage of the total PLFA at all stations were found for 14:0,

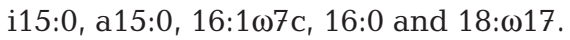

Of the 36 fatty acids, 14 fatty acids (12:0, 13:0, 3OH12:0, 3-OH14:0, 16:1 15 (marker for the CytophagaFlavobacterium-Bacteroides phylum), 17:1, 10Me18:0 (marker for Actinomycetes spp.), cy19:0 (marker for Desulfobacter spp.) and all PLFAs $>\mathrm{C}_{20}$ (marker for eukaryotes) were significantly more abundant in the German Bight, the Skagerrak and the Kattegat than in all other areas; 7 additional fatty acids (i14:0, br17:0, 10Me16:0 [marker for Desulfobacter spp.], cy17:0 [marker for Desulfobacter spp.], 17:0, 18:1 b $_{\mathrm{b}}$ and 18:0) were also present in significantly higher quantities in these areas compared with the remaining sites. Also,

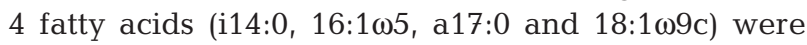
significantly more abundant in the Oyster Ground and southern Dogger Bank Stn DB12 than in the Dogger Bank and the eastern North Sea stations.

In addition to the marker fatty acids 24:0, 10Me18:0 and 16:1 155 , the relative contribution of PUFA (marker for microeukaryotes), cyclopropyl fatty acids (marker for Desulfobacter spp.) and saturated fatty acids $>\mathrm{C}_{20}$ (marker for eukaryotes) were significantly higher in the German Bight, the Skagerrak and the Kattegat compared to the other sites. The relative contribution of 10Me16:0 (marker for Desulfobacter spp.) decreased from the German Bight towards the open and eastern North Sea, where MUFAs (marker for aerobic prokaryotes) and trans fatty acids (marker for physiological stress) were highest.

\section{Macrofauna species number, abundance and biomass}

The macrofaunal distributions differed from the sediment and microbial patterns (Table 2). Species numbers and abundance were highest in the inner German Bight (Stns TS2 and TS4) in May and September and in the Kattegat in May, but lowest at Stn TS5 in May and September. A decreasing trend from the German Bight towards the Dogger Bank was only found for species numbers in May. The remaining stations in both months displayed fairly similar species numbers.

In the southern North Sea, maximum abundance was found in the inner German Bight (Stns TS2 and TS4) (Table 2). Abundance decreased abruptly at Stn TS5 and remained stable towards the Dogger Bank, except at Stn DB11 in May. Abundance in the eastern North Sea was generally lower in May than in September. Highest variability in abundance was at Stn EN2, where the lowest abundance in this region was found in May and the highest in September, when it ex- ceeded even values for the inner German Bight. Abundance in the Skagerrak and Kattegat were comparable with that in the inner German Bight in May and September as well as with the eastern North Sea in September only.

Biomass did not show any regular pattern (Table 2). In May, biomass was high in the inner German Bight, the Oyster Ground, and at Stns DB11 and DB12 and EN5 compared to the remaining stations. In September, the inner German Bight and Stns TS4, TS7, TS8, EN2 and KT also displayed the highest biomass.

Macrofaunal abundance correlated significantly with mud and TOC concentrations in May, and with biomass in September (Table 3).

\section{Macrofaunal community structure}

Although only $0.04 \mathrm{~m}^{2}$ of the communities were sampled per station and month, the species given in Table 4 represent the dominant or characteristic species of well-known communities documented in several earlier studies (Salzwedel et al. 1985, Kröncke \& Rachor 1992, E. Rachor \& P. Nehmer unpubl. data). The Nucula nitidosa community occurs in the German Bight, the Amphiura filiformis in the Oyster Ground and the Skagerrak and Kattegat, the Fabulina fabula community in the eastern North Sea, and the Bathyporeia-Fabulina community on the Dogger Bank (Fig. 3).

In this study, the Nucula nitidosa community (Stns TS2-TS6) (Table 4) was dominated in May by the subsurface deposit-feeding polychaete Scalibregma inflatum, juvenile bivalves and asteroids, as well as juvenile Echinocardium spp. and N. nitidosa. In September 1999, this community extended over the whole Oyster Ground including Stns TS7 and TS8, as well as Stn DB 12 on the southern border of the Dogger Bank due to high numbers of juveniles of ophiurids, N. nitidosa, Abra spp., Echinocardium spp., Fabulina fabula and Ensis spp. (for feeding modes see Table 4). In contrast, the Oyster Ground is known to be inhabited by the Amphiura filiformis community dominated by the ophiurid A. filiformis and it's commensal bivalve Mysella bidentata.

The Fabulina fabula community in the eastern North Sea (Stns EN1 to EN5) was dominated in May 2000 by the small episammic browsing echinoid Echinocyamus pusillus, juvenile asteroids, the deposit-feeding bivalve Corbula gibba, as well as nemerteans and several polychaete species such as Pholoe balthica, Chaetozone setosa, Spiophanes bombyx etc. (Table 4). In September, a dramatic increase in phoronids occurred found with maximum numbers of $44478 \mathrm{~m}^{-2}$ at Stn EN2. Additionally, juvenile F. fabula, ophiurids, 
Table 4. Mean abundance, $\mathrm{N}$ (no. $\mathrm{m}^{-2}$ ) of dominant species and feeding types (Mode) of macrofaunal communities. IF: interfacefeeder; SF: suspension-feeder; SD: surface deposit-feeder; SSD: subsurface deposit-feeder; P: predator; SL: sand-licker; G: grazer; station abbreviations as in Table 1

\begin{tabular}{|c|c|c|c|c|c|}
\hline \multicolumn{3}{|l|}{ May } & \multicolumn{3}{|c|}{ September } \\
\hline Species & $\mathrm{N}$ & Mode & Species & $\mathrm{N}$ & Mode \\
\hline \multicolumn{3}{|l|}{$\begin{array}{l}\text { Nucula nitidosa community } \\
\text { (German Bight, Stns TS2-TS6) }\end{array}$} & \multicolumn{3}{|c|}{$\begin{array}{l}\text { Nucula nitidosa + Amphiura filiformis communities } \\
\text { (Stns TS2-TS8, DB12) }\end{array}$} \\
\hline Scalibregma inflatum & 1229 & SSD & Ophiura juveniles & 1147 & $\mathrm{SD}$ \\
\hline Bivalvia juveniles & 851 & $\mathrm{SF}$ & Hydrozoa & 1072 & IF/HP \\
\hline Echinocardium juveniles & 753 & $\mathrm{SD}$ & Nucula nitidosa & 376 & SSD \\
\hline Nucula nitidosa & 284 & SSD & Abra juveniles & 341 & $\mathrm{SD}$ \\
\hline Asteroidea juveniles & 182 & $\mathrm{P}$ & Mysella bidentata & 170 & $\mathrm{SF}$ \\
\hline Spiophanes bombyx & 126 & IF & Echinocardium juveniles & 107 & $\mathrm{SD}$ \\
\hline Lanice conchilega & 119 & IF & Spiophanes bombyx & 123 & IF \\
\hline Mysella bidentata & 49 & $\mathrm{SF}$ & Fabulina fabula juveniles & 101 & IF \\
\hline Nephtys juveniles & 42 & $\mathrm{P}$ & Ensis ensis & 99 & $\mathrm{SF}$ \\
\hline Eumida sanguinea & 35 & $\mathrm{P}$ & Spio decorata & 60 & IF \\
\hline \multicolumn{3}{|l|}{$\begin{array}{l}\text { Fabulina fabula community } \\
\text { (Eastern North Sea, Stns EN1-EN5, TS7) }\end{array}$} & \multicolumn{3}{|c|}{$\begin{array}{l}\text { Fabulina fabula community } \\
\text { (Eastern North Sea, Stns EN2-EN5) }\end{array}$} \\
\hline Echinocyamus pusillus & 552 & SL & Phoronis spp. & 13832 & $\mathrm{SF}$ \\
\hline Asteroidea juveniles & 431 & $\mathrm{P}$ & Fabulina fabula juveniles & 868 & IF \\
\hline Corbula gibba juveniles & 314 & SF & Ophiura juveniles & 714 & $\mathrm{SD}$ \\
\hline Nemertini & 90 & $\mathrm{P}$ & Nemertini & 427 & $\mathrm{P}$ \\
\hline Pholoe balthica & 64 & $\mathrm{P}$ & Spio spp. & 245 & IF \\
\hline Chaetozone setosa & 59 & $\mathrm{SD}$ & Magelona filiformis & 238 & IF \\
\hline Spiophanes bombyx & 56 & IF & Phaxas pellucidus juveniles & 217 & $\mathrm{SF}$ \\
\hline Magelona filiformis & 53 & IF & Spiophanes bombyx & 161 & IF \\
\hline Phoronis spp. & 39 & $\mathrm{SF}$ & Chamelea gallina juveniles & 140 & $\mathrm{SF}$ \\
\hline Fabulina fabula juveniles & 28 & IF & Magelona johnstoni & 119 & IF \\
\hline \multicolumn{3}{|c|}{$\begin{array}{l}\text { Bathyporeia-Fabulina + Amphiura filiformis communities } \\
\text { (Dogger Bank border, Stns TS8, DB9, DB12) }\end{array}$} & \multicolumn{3}{|c|}{$\begin{array}{l}\text { Bathyporeia-Fabulina community } \\
\text { (Dogger Bank, Stns TS9, DB9, DB11) }\end{array}$} \\
\hline Hydrozoa & 467 & IF & Spiophanes bombyx & 536 & $\mathrm{IF}$ \\
\hline Spiophanes bombyx & 331 & IF & Bathyporeia juveniles & 302 & SL \\
\hline Bivalvia juveniles & 294 & $\mathrm{SF}$ & Bathyporeia elegans & 280 & SL \\
\hline Bathyporeia elegans & 280 & SL & Nemertini & 126 & $\mathrm{P}$ \\
\hline Mysella bidentata & 215 & $\mathrm{SF}$ & Ophiura juveniles & 98 & $\mathrm{SD}$ \\
\hline Magelona johnstoni & 131 & IF & Urothoe poseidonis & 81 & SL \\
\hline Nemertini & 84 & $\mathrm{P}$ & Spio decorata & 76 & $\mathrm{IF}$ \\
\hline Amphiura filiformis & 70 & $\mathrm{IF}$ & Fabulina fabula juveniles & 70 & IF \\
\hline Urothoe poseidonis & 70 & SL & Perioculodes longimanus & 53 & SL \\
\hline Magelona filiformis & 56 & IF & Lanice conchilega & 50 & IF \\
\hline \multicolumn{6}{|l|}{$\begin{array}{l}\text { Bathyporeia-Fabulina community } \\
\text { (DB Tail End + centre, Stns TS9, DB11) }\end{array}$} \\
\hline Echinocardium juveniles & 7581 & SL & & & \\
\hline Spiophanes bombyx & 723 & $\mathrm{IF}$ & & & \\
\hline Bathyporeia elegans & 114 & SL & & & \\
\hline Magelona filiformis & 102 & $\mathrm{IF}$ & & & \\
\hline Hydrozoa & 93 & $\mathrm{IF}$ & & & \\
\hline Nemertini & 84 & $\mathrm{P}$ & & & \\
\hline Lagis koreni & 70 & SSD & & & \\
\hline Lanice conchilega & 63 & IF & & & \\
\hline Urothoe poseidonis & 35 & SL & & & \\
\hline Spio decorata & 30 & IF & & & \\
\hline \multicolumn{3}{|l|}{$\begin{array}{l}\text { Amphiura filiformis community } \\
\text { (Skagerrak/Kattegat) }\end{array}$} & \multicolumn{3}{|l|}{$\begin{array}{l}\text { Amphiura filiformis community } \\
\text { (Skagerrak/Kattegat) }\end{array}$} \\
\hline Ophiura juveniles & 1939 & $\mathrm{SD}$ & Myriochele spp. & 2118 & IF \\
\hline Mysella bidentata & 616 & SF & Mysella bidentata & 1050 & $\mathrm{SF}$ \\
\hline Pholoe balthica & 224 & $\mathrm{P}$ & Phoronis spp. & 618 & SF \\
\hline Amphiura filiformis juveniles & 224 & IF & Ophiura juveniles & 497 & SD \\
\hline Nemertini & 189 & $\mathrm{P}$ & Pholoe balthica & 399 & $\mathrm{P}$ \\
\hline Amphiura filiformis & 168 & IF & Amphiura filiformis juveniles & 390 & IF \\
\hline Diplocirrus glaucus & 105 & SD & Nemertini & 173 & $\mathrm{P}$ \\
\hline Spio spp. & 84 & IF & Oligochaeta & 89 & SSD \\
\hline Tanaidacea & 56 & $\mathrm{SD}$ & Diplocirrus glaucus & 42 & $\mathrm{SD}$ \\
\hline Levinsenia gracilis & 49 & SSD & Gastropoda indeterminate & 42 & $\mathrm{G}$ \\
\hline
\end{tabular}


Nemertini, Spio spp., Magelona filiformis and $M$. johnstoni were present.

On the Dogger Bank, the typical Bathyporeia-Fabulina community was found, represented by dominant species such as the interface-feeding polychaetes Spiophanes bombyx, Magelona johnstoni and M. filiformis, the sand-licking amphipod Bathyporeia elegans, and other amphipods such as Urothoe poseidonis, and Perioculodes longimanus (Table 4). In May, the Dogger Bank stations were divided into different communities due to extremely high abundances of juvenile Echinocardium spp.

The Skagerrak and Kattegat stations were also inhabited by the Amphiura filiformis community, and were clearly separated from the other areas in both May and September (Fig. 3). In May, The communities were dominated by juvenile ophiurids and the commensal bivalve Mysella bidentata (Table 4). Juvenile and adult $A$. filiformis occurred also in high mean abundances. Pholoe balthica and other small surface- and subsurfacefeeding polychaetes such as Diplocirrus glaucus, Spio spp. and Levinsenia gracilis were also found in these communities. In September, Myriochele spp. dominated the communities. Minor abundant species were again $M$. bidentata, Phoronis spp. and oligochaetes (Table 4).
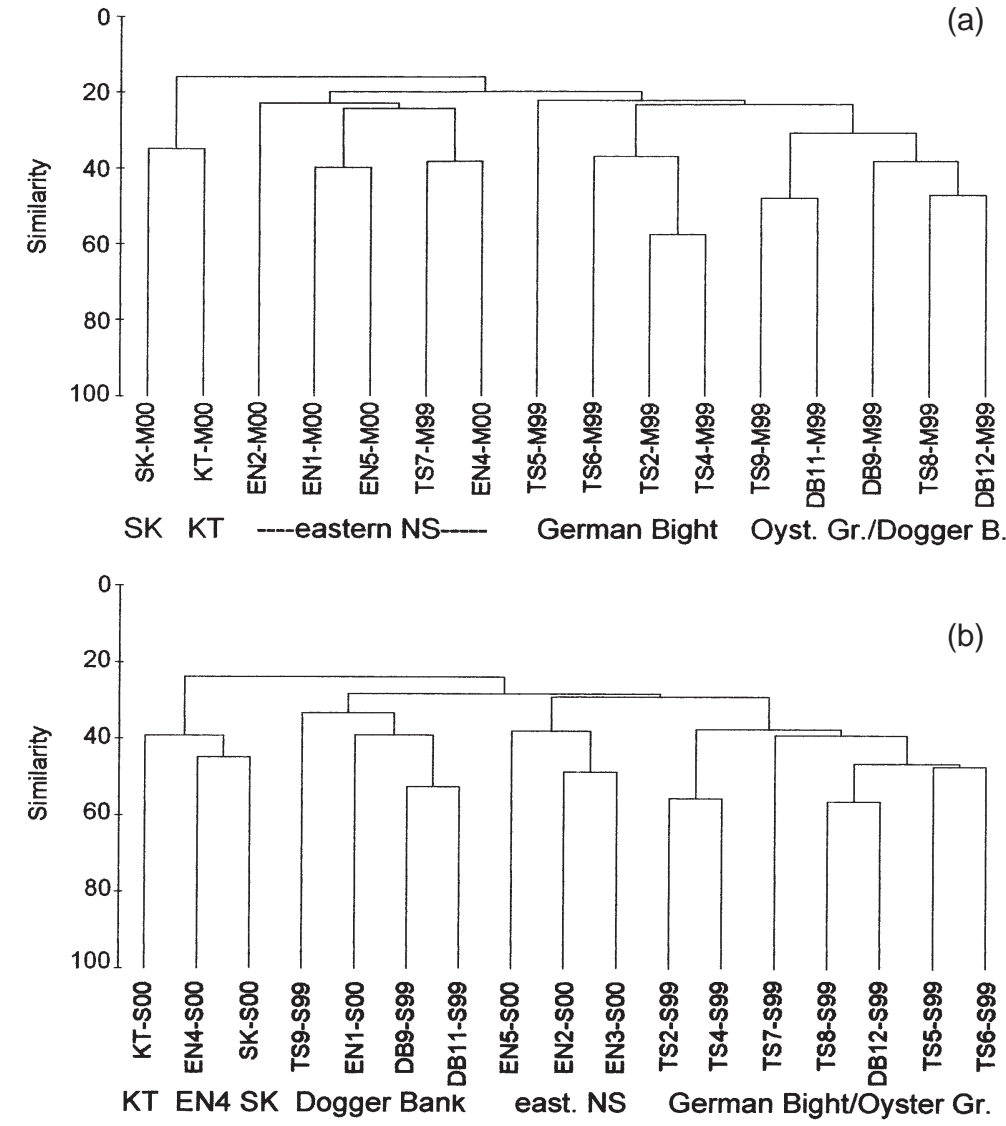

Fig. 3. Dendrograms for macrofaunal communities (abundance) in May (a) and September (b) 1999 and 2000 in the German Bight (GB), Oyster Ground, at the Dogger Bank (DB), in the eastern North Sea (EN) and in the Skagerrak (SK) and Kattegat (KT)

\section{Macrofaunal abundance related to microbial and sediment parameters}

We used canonical correspondence analyses (CCA) to analyse and demonstrate the relationship between sediment parameters, microbial and macrofaunal community structure and function. The CCA for May revealed that the first canonical axis is a significant function of a chl a gradient $(\mathrm{r}=0.73)$ (Fig. 4). The stations related to the first axis were Stns TS2 to TS5 from the German Bight. The second axis is a function of RNA ( $\mathrm{r}=-0.85$ ) and mud concentrations ( $\mathrm{r}=-0.79$ ), with DNA-C biomass and bacterial abundance being further significant variables. The mud gradient was associated by the most muddy stations in the Kattegat, Skagerrak and Stn EN2 in the eastern North Sea.

A similar pattern was observed in September, with the Skagerrak and Kattegat stations again related to the mud gradient, and the German Bight stations to the RNA, chl $a$ and DNA-C concentrations gradients. The environmental gradients explained $45 \%$ of the macrofaunal abundance pattern.

\section{Macrofaunal biomass related to microbial and sediment parameters}

Similar to abundance, the biomass of communities in the German Bight in both months and in the eastern North Sea in September was related to gradients of chl $a$, RNA and TBC. The environmental gradients explained $60 \%$ of the macrofaunal biomass pattern in May and $76 \%$ in September.

\section{Relation between taxonomic groups and microbial and sediment parameters}

A relationship between taxonomic groups and microbial and sediment parameters was not detectable in May or September. Phoronids and cumaceans showed a slight preference for the TOC gradient. It was obvious that groups whose food resources are not directly connected with the sediment (such as predatory decapods and anthozoa, hydrozoa, ophiurids and amphiurids) were poorly related to sediment parameters. 


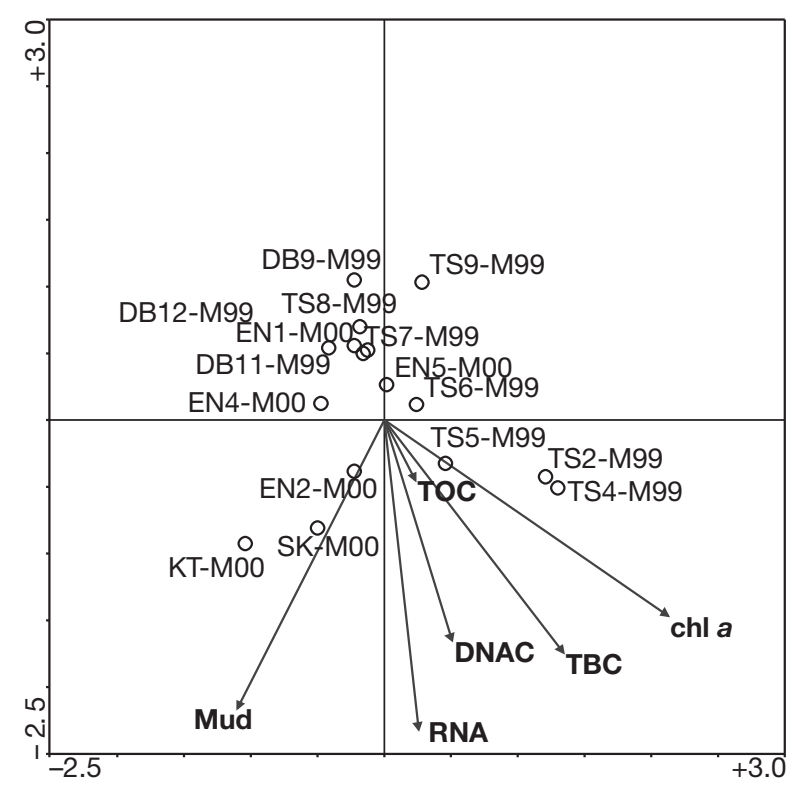

Fig. 4. CCA revealing relationship between macrofaunal community (abundance) and microbial and sediment parameters in May 1999 and 2000. Circles represent the station positions within the ordination space. Vector lines represent the relationship of significant environmental variables to the ordination axes, and their length is proportional to their relative significance. TOC: total organic carbon; chl a: chlorophyll $a_{\text {; }}$ TBC: total bacteria counts; DNA-C: microbial biomass; RNA: microbial activity; station abbreviations as in Table 1

\section{Relation between feeding modes and microbial and sediment parameters}

Using feeding modes instead of abundance, the CCAs revealed a closer relationship between all measured sediment and microbial parameters and subsurface-feeders and to lesser extent surface deposit-feeders as well as suspension-feeders and omnivores. Sand-lickers, interface-feeders and predators displayed no relationship with any gradient (Fig. 5).

\section{Relation between macrofaunal and microbial community structure}

Despite co-linearity, all PLFAs were included in the CCAs to achieve a preliminary insight into the relationship between microbial (PLFA) and macrofaunal community structure. However, PLFA data were not available for all stations sampled for macrofauna, and thus, the statistical analyses are restricted to Stns TS2 (German Bight), TS7 (Oyster Ground), DB9, DB11, DB12 (Dogger Bank), EN5 (eastern North Sea), SK (Skagerrak) and KT (Kattegatt) for May and September 2000 .

\section{Macrofaunal abundance and PLFAs}

Fig. 6 gives an example of the general relationship between macrofaunal and microbial (PLFA) community patterns in May (Fig. 6a) and September (Fig. $6 b)$. Both axes explain 37 to $41 \%$ of the macrofaunal abundance pattern in May and September. The first species axis were significantly explained by the PLFAs 10Me16:0 = sulphate reducing bacteria $(\mathrm{r}=$ 0.63) and 16:1 $\omega 5=$ Cytophaga-Flavobacterium-Bacteroides phylum $(\mathrm{r}=0.62)$, which were closely associated with the macrofaunal communities of the Skagerrak (SK) and Kattegat (KT) stations. The second axis was a function of most of the PLFAs, but faunal communities were not closely related to any of these gradients. However, communities of Stns TS2, TS7, TS9, EN5 and DB9-12 were associated with the gradients of PLFAs 16:00, 16:1 $107 \mathrm{c}, 18: 1 \omega 9 \mathrm{c}$, 10Me17:0, 17:00, i17:00 and br17:0, which are characteristic for bacteria and reflect the general microbial and macrofaunal patterns and relationships revealed by the CCA in Fig. 4.

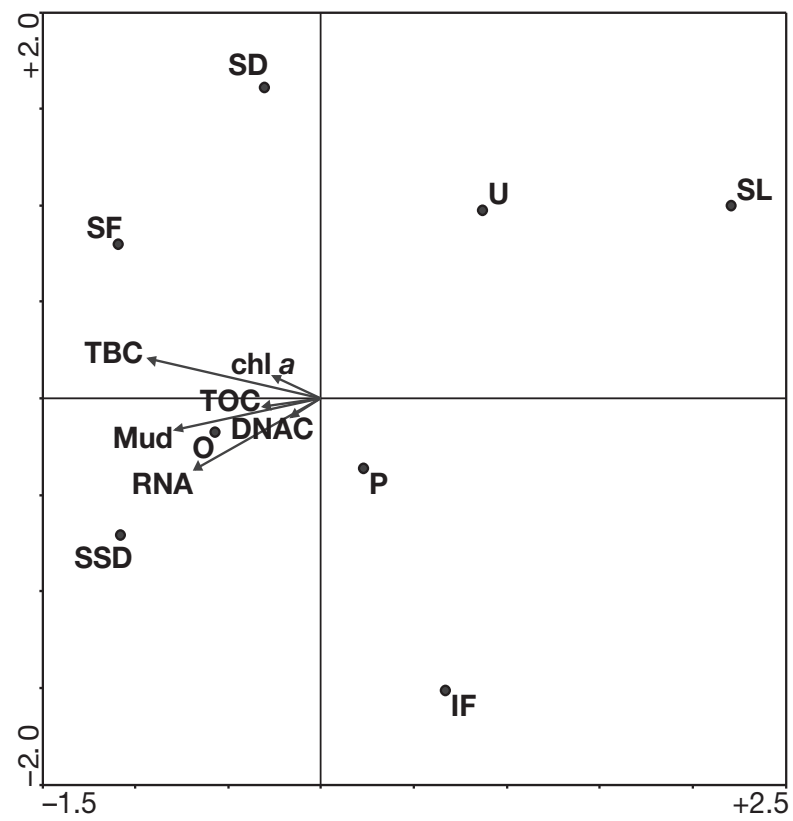

Fig. 5. CCA revealing relationship between macrofaunal feeding modes and microbial and sediment parameters. Dots represent the positions of feeding types contributing significantly to the biological variance. Vector lines represent the relationship of significant environmental variables to the ordination axes, and their length is proportional to their relative significance. TOC: total organic carbon; chl a: chlorophyll $a_{\text {; }}$ TBC: total bacteria counts; DNA-C: microbial biomass; RNA: microbial activity; IF: interface-feeder; SF: suspension-feeder; SD: surface deposit-feeder; SSD: subsurface deposit-feeder;

P: predator; SL: sand-licker; O: omnivore; U: unknown 

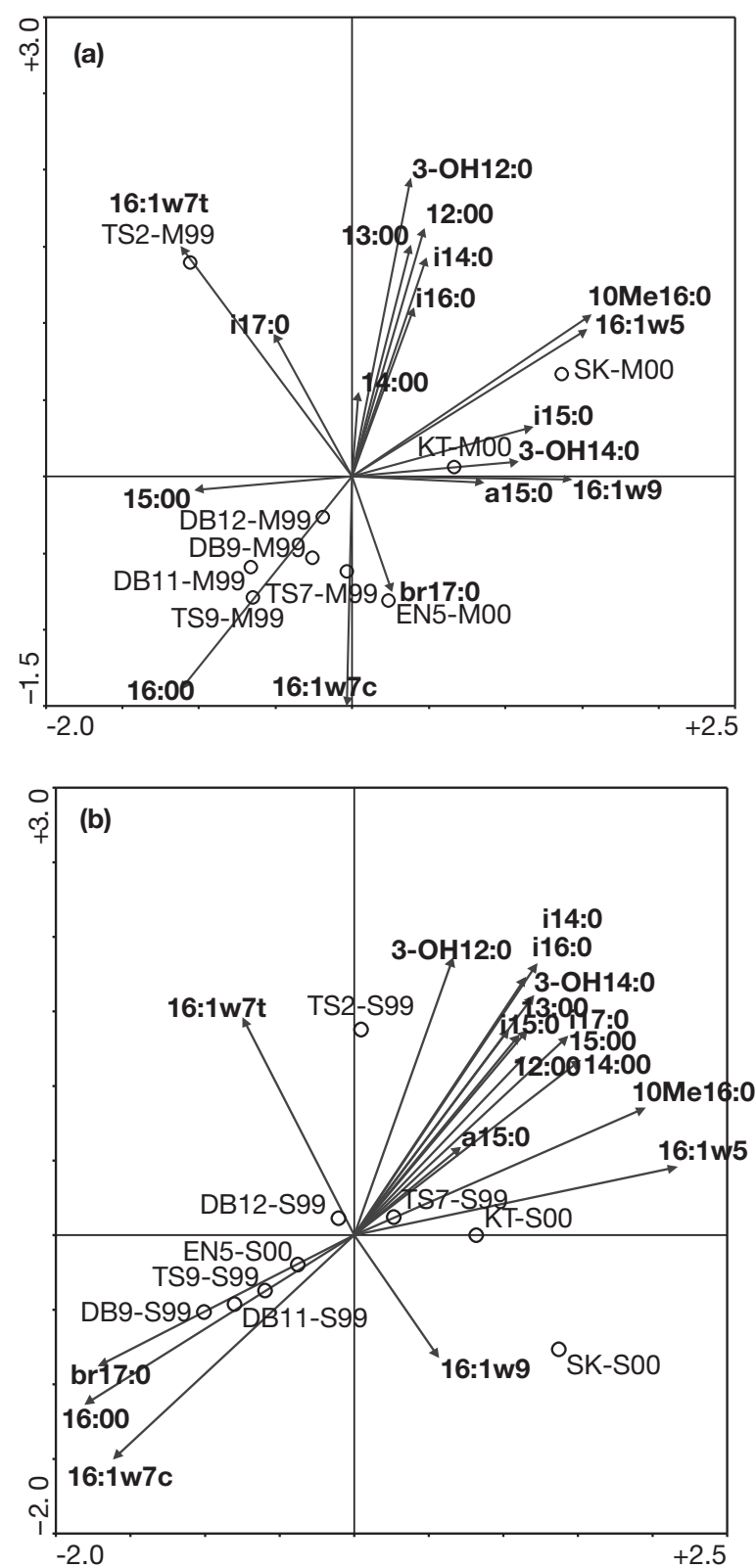

Fig. 6. CCA revealing relationship between macrofaunal (abundance) and microbial (PLFAs) community structure in May (a) and September (b) 1999 and 2000. Circles represent the station positions within the ordination space. Vector lines represent the relationship of significant PLFAs to the ordination axes, and their length is proportional to their relative significance; station abbreviations as in Table 1

\section{Macrofaunal biomass and PLFAs}

In terms of biomass (Fig. 7), the communities were structured mainly along the second axis, which was explained by the PLFA gradients 10Me16:0 (marker for Desulfobacter spp.) $(\mathrm{r}=-0.67), 17: 00(\mathrm{r}=-0.6), \mathrm{a} 17: 0$ $(\mathrm{r}=-0.6), 17: 01(\mathrm{r}=-0.5), 16: 105(\mathrm{r}=-0.45), 20: 04(\mathrm{r}=$ $-0.42), 15: 00(\mathrm{r}=-0.47), \mathrm{i} 16: 0(\mathrm{r}=-0.43)$, br17:0 $(\mathrm{r}=$ 0.49), cy17:0 (marker for Desulfobacter spp.) ( $\mathrm{r}=-0.46)$ and associated with the communities of Stns SK, KT, DB11, EN5 and TS9. Only Stns DB9 and 12 were

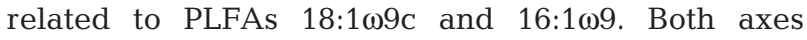
explain $66 \%$ of the macrofaunal biomass pattern in May and September.

\section{Relation between taxonomic groups and sediment parameters}

The most obvious relationship between macrofaunal feeding modes and the microbial PLFA pattern was that amphipods and decapods occurred at higher than average densities at PLFAs 16:00,

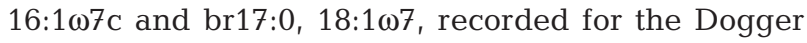
Bank Stns DB9 and DB12 and may thus be markers for amphipods or amphipod-related microbes or substrates. Bivalve, echinoids and gastropod occurrence was associated with most PLFAs (Fig. 8), while polychaetes occurred in higher average abundances at PLFAs 15:0, 15:00 and 20:00 and cy17:0. Abundance of cumaceans and nemerteans was not related to any PLFA.

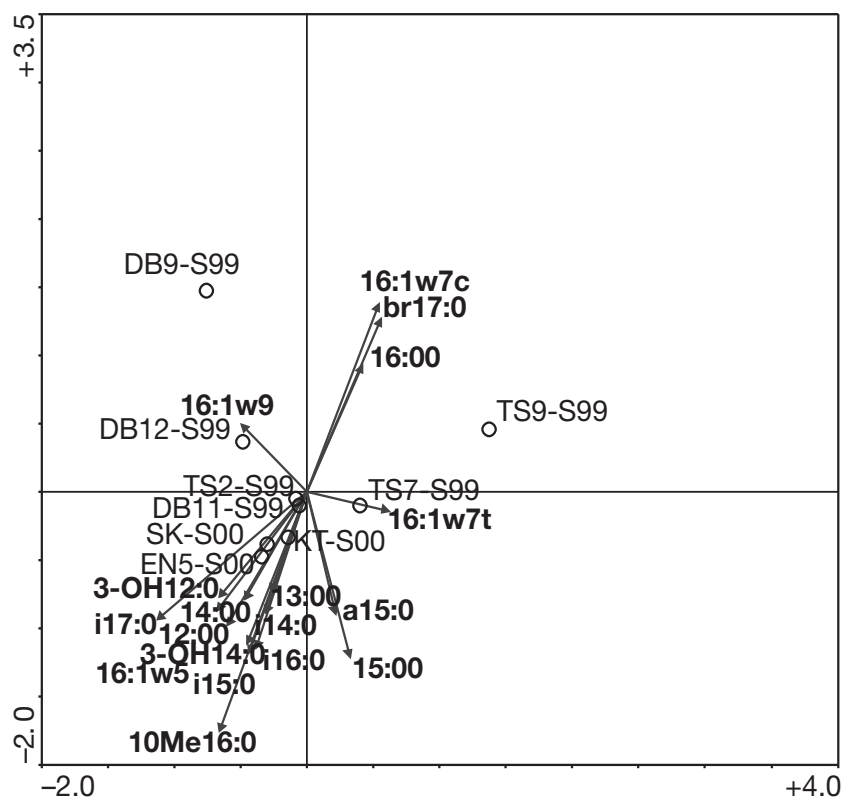

Fig. 7. CCA revealing relationship between macrofaunal (biomass) and microbial (PLFAs) community structure in September 1999 and 2000. Circles represent the station positions within the ordination space. Vector lines represent the relationship of significant PLFAs to the ordination axes, and their length is proportional to their relative significance; station abbreviations as in Table 1 


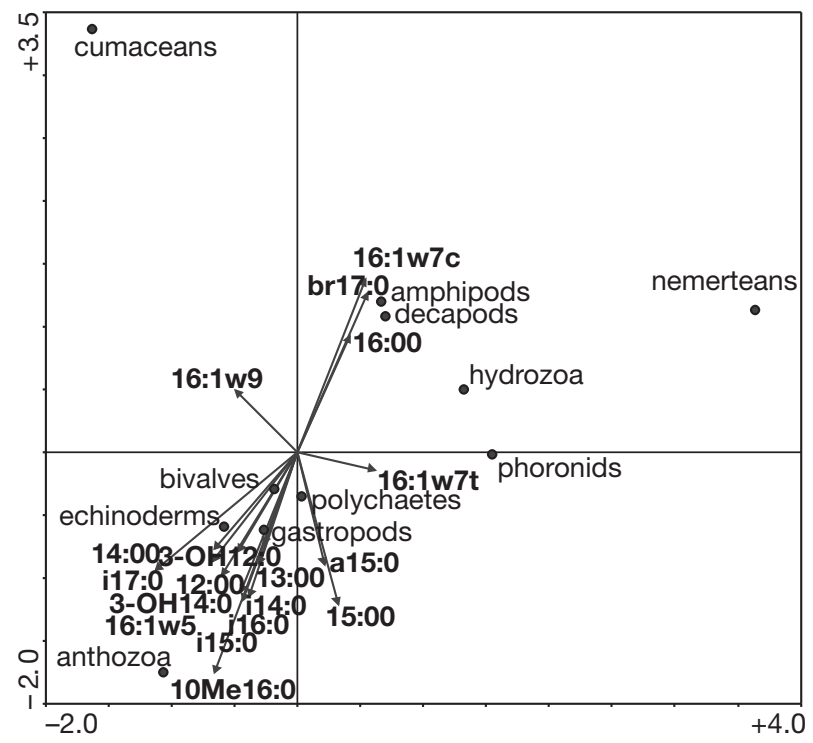

Fig. 8. CCA revealing relationship between taxonomic groups and microbial (PLFA) community structure. Dots represent the positions of taxonomic groups contributing significantly to the biological variance. Vector lines represent the relationship of significant environmental variables to the ordination axes, and their length is proportional to their relative significance; station abbreviations as in Table 1

\section{DISCUSSION}

The results of the first quantitative macrofaunal investigation in the eastern North Sea in the 1920s by Hagmeier (1925), the large-scale investigation in the 1970s by Salzwedel et al. (1985), the studies by Kröncke \& Rachor (1992) and E. Rachor \& P. Nehmer (unpubl. data) in 1990 and in 2000, and the present study, all suggest that the spatial distribution of macrofaunal communities has remained fairly stable over time. Our results show that the spatial distribution of the structure of microbial (PLFAs) and macrofaunal communities is congruent, generally due to functional (trophic) factors and is thus a function of food availability, since both microbial and macrofaunal communities were significantly correlated with chl a and TOC concentrations in the sediments (Josefson \& Conley 1997, Josefson 1998). We shall therefore discuss differences in food availability in relation to the variability in environmental parameters at the different study sites (Table 5).

\section{Gradients of environmental parameters}

The decreasing gradients of mud, TOC and chl a concentrations from the German Bight towards the Dogger Bank result from differences in production and sedi- mentation of organic matter (Eisma \& Kalf 1987, Joint \& Pomroy 1993, Kröncke \& Knust 1995, de Haas \& van Weering 1997, Puls et al. 1997, Hickel 1998). A sediment map for the whole North Sea (Basford et al. 1993) revealed that most of the sediments are sands, indicating that in most parts of the North Sea little deposition occurs.

The highest mud and TOC concentrations recorded in this study confirm that the only depositional site in the southern North Sea is the inner German Bight (Figge 1981), where deposition is largely due to currents and morphological features (Aigner \& Reineck 1982, Becker et al. 1992, Dippner 1993); the high loads of suspended matter and nutrients transported by the river Elbe into the German Bight (Eisma \& Kalf 1987, de Haas et al. 1997, Puls et al. 1997, Dauwe \& Middelburg 1998); and high primary production, especially in spring (Joint \& Pomroy 1993, Hickel 1998, Stoeck \& Kröncke 2001, H. Reiss \& I. Kröncke unpubl. data). The net input of labile organic matter into the sediment is so high (de Haas \& van Weering 1997) that large amounts of organic matter are buried into deeper sediments by bioturbation (Dauwe et al. 1998, H. Reiss \& I. Kröncke unpubl. data). The organic matter deposited in the German Bight is rich in bioavailable nitrogen, and thus of high quality (Dauwe \& Middelburg 1998).

In contrast, the Oyster Ground is assumed to be an area of low sedimentation rates and net deposition (Cadée 1984, Boon et al. 1999) due to stratification and currents. This results in lower mud and TOC concentrations than in the inner German Bight. Deposition and resuspension of aggregated organic matter occur in this area (Jones et al. 1998), and are related to the feeding modes of the dominant macrofaunal species. In the eastern North Sea, we measured TOC and chl a concentrations similar to those in the Oyster Ground and in the southern Dogger Bank Stn DB12, indicating similarities in currents, production and sedimentation.

The Dogger Bank is known to be an area strongly affected by hydrodynamics (Kröncke \& Knust 1995, Wieking \& Kröncke 2001, 2003). Sedimentation rates are low, resuspension rates high (Wirth \& Wiesner 1988), and mud and TOC concentrations low. Thus, the benthic system only partially benefits from the high primary production observed throughout the year in the Dogger Bank area (Brockmann \& Wegner 1985, Riegman et al. 1990, Joint \& Pomroy 1993, Nielsen et al. 1993, Stoeck \& Kröncke 2001, Wieking \& Kröncke 2003). Since chl a concentrations on the Dogger Bank were similar to those measured for the Oyster Ground and the eastern North Sea, benthic primary production seems to be important in this shallow area, where light penetration reaches the sea floor and sufficient nutrients are available in the water column throughout the year (Riegman et al. 1990, Nielsen et al. 1993). No data on benthic primary production are available, but Wieking \& Kröncke (2001, 
2003) inferred from the dominance of amphipods (which browse on microalgae on sand grains) that benthic primary production comprises a major food source for this community (Wieking \& Kröncke in press).

The Skagerrak is the major sink for particles produced and resuspended in the North Sea (van Weering et al. 1993, Josefson et al. 1993, de Haas \& van Weering 1997) as reflected by the high mud concentrations recorded in the present study. Similar or higher TOC but lower chl a concentrations in the Skagerrak than in the German Bight reflect that the POC deposited in the Skagerrak is highly refractory (Dauwe \& Middelburg 1998, Dauwe et al. 1999) with up to $20 \%$ being of ter- restrial origin (Liebezeit 1987, Anton et al. 1993, Meyenburg \& Liebezeit 1993, de Haas \& van Weering 1997) compared to the fresh nitrogen-rich POC in the German Bight or the Oyster Ground (Dauwe \& Middelburg 1998, Dauwe et al. 1999).

\section{Microorganisms, macrofauna and environmental parameters}

In May, bacterial counts as well as microbial biomass and activity were significantly correlated with mud, TOC and chl a concentrations, indicating that the

Table 5. Characteristics of study sites and communities. Abbreviations as in Table 2

\begin{tabular}{|c|c|c|c|c|c|}
\hline Parameter & ierman Bight & Oyster Ground & Dogger Bank & Eastern North Sea & Skagerrak/Kattegat \\
\hline Chl a & High & Moderate & Moderate & Moderate & Moderate \\
\hline TOC & High & Moderate & Low & Moderate & High \\
\hline Mud & High & Moderate-low & Low & Moderate & High \\
\hline TBC & High & Moderate & Moderate to low & w Low & Moderate to low \\
\hline DNA & High & Moderate & Moderate & Moderate to high & Moderate \\
\hline RNA & High & Moderate & Moderate & Moderate & Moderate \\
\hline No. PLFAs & High & Moderate & Low & Low & High \\
\hline Biomass of PLFAs & High & Moderate & Moderate & Moderate & High \\
\hline Marker PLFAs for bacteria & High & Moderate & Low & Low & High \\
\hline $\begin{array}{l}\text { Marker PLFAs for } \\
\text { microeukaryotes }\end{array}$ & High & Low & Low & Low & High \\
\hline $\begin{array}{l}\text { Marker PLFAs for sulphate- } \\
\text { reducing bacteria, } \\
\text { Desulfobacter }\end{array}$ & High & Moderate & Moderate & Moderate & High \\
\hline $\begin{array}{l}\text { Marker PLFAs for the } \\
\text { genera Cytophaga- } \\
\text { Flavobacterium-Bacteroides } \\
\text { Actinomycetes (organic } \\
\text { enriched, macromolecules) }\end{array}$ & High & Low & Low & Low & High \\
\hline $\begin{array}{l}\text { Marker PLFAs for } \\
\text { physiological stress, } \\
\text { food limitation }\end{array}$ & Moderate & Low & High & High & Moderate \\
\hline Preferred utilised substrate & $\begin{array}{l}\text { Amino acids, } \\
\text { carbohydrates }\end{array}$ & Glycogen & $\begin{array}{l}\text { Amino acids, } \\
\text { carbohydrates, } \\
\text { dextrin }\end{array}$ & & \\
\hline \multicolumn{6}{|l|}{ Macrofauna } \\
\hline Species & High & High & High & Moderate & High \\
\hline Abundance & High & Moderate & Low to high & Low to high & High \\
\hline Biomass & High & High & Low to high & Low to high & Low to high \\
\hline Feeding types & $\begin{array}{l}\text { Subsurface- } \\
\text { deposit-, surface- } \\
\text { deposit and } \\
\text { interface feeders, } \\
\text { predators }\end{array}$ & $\begin{array}{l}\text { Interface-, } \\
\text { and surface- } \\
\text { deposit feeders }\end{array}$ & $\begin{array}{l}\text { Sand-licker, } \\
\text { interface-, and } \\
\text { surface-deposit } \\
\text { feeders }\end{array}$ & $\begin{array}{l}\text { Sand-licker, } \\
\text { suspension } \\
\text { feeders, interface } \\
\text { feeders, surface- } \\
\text { deposit feeders }\end{array}$ & $\begin{array}{l}\text { Interface feeders, } \\
\text { surface-deposit } \\
\text { feeders, suspension } \\
\text { feeders }\end{array}$ \\
\hline $\begin{array}{l}\text { Food competition } \\
\text { (microbes vs macrofauna) }\end{array}$ & $\begin{array}{l}\text { None: sufficient } \\
\text { food }\end{array}$ & $\begin{array}{l}\text { Yes, macrofauna } \\
\text { provides microbes } \\
\text { with food, microbes } \\
\text { utilise macrofaunal } \\
\text { excretion products }\end{array}$ & $\begin{array}{l}\text { Yes } \\
\text { es } \\
\text { ll }\end{array}$ & Yes & $\begin{array}{l}\text { No for amount of } \\
\text { organic matter, } \\
\text { yes for fresh } \\
\text { organic matter }\end{array}$ \\
\hline Macrofaunal community & Nucula nitidosa & $\begin{array}{l}\text { Amphiura } \\
\text { filiformis }\end{array}$ & $\begin{array}{l}\text { Bathyporeia- } \\
\text { Fabulina }\end{array}$ & Fabulina fabula & Amphiura filiformis \\
\hline
\end{tabular}


abundance of microbial organisms is generally controlled by food supply, as also found by van Duyl et al. (1993), Upton et al. (1993), van Duyl \& Kop (1994), Osinga et al. (1996) and Stoeck \& Kröncke (2001).

Macrofaunal abundance was significantly correlated with mud and TOC concentrations in May. Wieking \& Kröncke (2003) showed that the abundance of the sea urchin Echinocardium cordatum at the Dogger Bank was also significantly correlated with TOC concentrations, but that growth was correlated with chl a concentrations. Thus, the amount of particulate organic matter is the first-order parameter controlling macrofaunal abundance (Sibuet et al. 1989), since carbon is essential for metabolic (calorimetric) requirement and even refractory organic matter seems sufficient to meet energetic needs (Tenore 1983, Tenore \& Chesney 1985). In contrast, the quality of the organic matter seems to be essential for recruitment and growth (Wieking \& Kröncke 2003).

However, for the German Bight stations, the CCAs revealed a significant relationship between macrofaunal abundance and biomass, as well as between microbial activity and biomass and chl a concentration. The latter is an indicator of fresh, and high-quality food (Boon \& Duineveld 1998). Thus, high-quality food from the water column seems to be a key factor in structuring both macrofauna and microbial communities. The quick and direct response of microorganisms to an input of fresh organic matter has been described in many studies for different marine areas (Aller \& Yingst 1980, Middelburg et al. 1993, Boetius \& Lochte 1994, Kristensen et al. 1995). In contrast, at the community level, the CCA revealed a relationship between chl a concentration and macrofaunal species abundance and biomass, which seems to be related to the dominance of juvenile macrofaunal species. This indicates a response to the enhanced supply of fresh nitrogen rich food in the form of recruitment and growth, as confirmed by monthly samples of H. Reiss \& I. Kröncke (unpubl. data) in the same area.

The CCAs did not show this relationship for the other regions, where other factors may be more important. For example, the abundances of the macrofaunal communities at the Skagerrak and Kattegat stations were associated with the mud and TOC gradients in both months (May and September) and with a chl a/RNA gradient in May only. This indicates that the microbial and macrofaunal community structures were generally related to the presence of mud and the quantity of organic matter (TOC), with the input of fresh organic matter (chl a) being important for the community structure in spring only. Because of the greater depth of the Skagerrak and Kattegat stations, chl a concentrations were significantly lower than in the German Bight, but microbial biomass and activities were similar. This indicates that microbes in the Skagerrak and northern Kattegat may utilise more refractory organic matter for remineralisation because of the higher amounts of this food source in this area (Dauwe \& Middelburg 1998).

\section{Community structure, trophic modes and environmental parameters}

The Nucula nitidosa community in the inner German Bight (E. Rachor \& P. Nehmer unpubl. data) was to a large extent dominated by juvenile bivalves and echinoderms. These species forage as surface deposit or suspension feeders (Bridges et al. 1994, Marsh \& Tenore 1990) and may benefit from the high amounts of fresh organic matter produced in the water column. High chl a concentrations, which are markers of fresh and nitrogen-rich organic matter (Boon \& Duineveld 1998), reflect the availability of fresh organic matter for both macrofaunal and microbial communities (Stoeck et al. 2003). Thus, microbial parameters were higher in this area than in the open North Sea. High amounts of the Cytophaga-Flavobacterium-Bacteroides phylum represented e.g. by PLFA 16:105 and Actinomycetes by PLFA 10Me18:0 are known to occur in organic enriched sediments and are able to degrade complex macromolecular substrates (McCarthy 1989) such as artificial carbon polymers transported by the river Elbe (Dauwe \& Middelburg 1998). Also higher concentrations of $>\mathrm{C}_{20}$ PLFAs in this area (characteristic of microeukaryotes: Vestal \& White 1989) indicate a greater food supply (Stoeck et al. 2003).

The inner German Bight was the only area of those studied, where subsurface deposit-feeders such as the polychaete Scalibregma inflatum and the bivalve Nucula nitidosa also occurred in high abundance. In a depositional area such as the German Bight, the net input of labile organic matter into deeper sediment layers by sedimentation and bioturbation is extremely high (de Haas \& van Weering 1997, Dauwe et al. 1998, H. Reiss \& I. Kröncke unpubl. data). Subsurface deposit-feeders as well as microorganisms benefit from this food source (Osinga et al. 1996, Kristensen 2000). Both bacterial biomass and particulate organic matter can be used as food by subsurface deposit-feeding macrofauna (Rice \& Rhoads 1989, Kemp 1990, Marsh \& Tenore 1990). Generally, microorganisms are able to mineralise also more refractory organic matter, which is normally found in deeper sediment layers (Kristensen et al. 1995). Thus, high bacterial production (van Duyl \& Kop 1994) and mineralisation rates of organic matter are responsible for the extremely anoxic sediments in the German Bight, common in this area (Hickel et al. 1989, Duineveld et al. 1990, Niermann et al. 1990). The anoxic sediment conditions in 
the German Bight are also responsible for the presence of the typical marker PLFAs for sulphate reducing bacteria of the genus Desulfobacter (e.g. 10Me16:0) (for details see Stoeck et al. 2002).

The macrofaunal community in the Oyster Ground belong to the Amphiura filiformis community (E. Rachor \& P. Nehmer unpubl. data). In this study, this community was separated from the Nucula nitidosa community in May only, since in September the whole area was dominated by juvenile ophiurids and bivalves as well as hydrozoans. Moderately high chl a concentrations in May and September across the Oyster Ground hint at a high availability of fresh organic matter, which might favour growth, as indicated by the fairly high biomass observed in autumn, and recruitment throughout the year (also found by H. Reiss \& I. Kröncke unpubl. data).

The dominant species in this community was the brittlestar Amphiura filiformis, which forages as an interface feeder in areas with moderate currents (Otto et al. 1990, Wieking \& Kröncke 2001, 2003). A. filiformis captures macroflocculate organic matter from the water column - available in the Oyster Ground from tidal or wave resuspension (Jones et al. 1998). The originally organic-rich aggregates are only of moderate nutritious quality because of scavenging of inorganic and refractory compounds (Dauwe et al. 1998, Jones et al. 1998). Also the lack of subsurface deposit-feeders such as $\mathrm{Nu}$ cula nitidosa confirms the fact that the $A$. filiformis community occurs in areas with a lower burial of fresh organic matter than the German Bight.

Stoeck et al. (2002) showed that microbial communities associated with $A$. filiformis were not adapted to using fresh organic matter as food source but utilised glycogen, a sugar polymer originating from zooorganisms such as meio- and macrofauna. Thus, the higher microbial biomass and activity in September than in May (confirmed by Osinga et al. 1996), may be related to higher macrofaunal abundance at most stations in autumn. On the other hand, H. Reiss \& I. Kröncke (unpubl. data) found an additional increase in diatom-derived fucoxanthin in autumn in the Oyster Ground due to mixing of the water column, which provided an additional food supply to both the microbial and macrofaunal communities.

The stations in the Skagerrak and northern Kattegat are both inhabited by the Amphiura filiformis community (Josefson et al. 1993) despite differences in water depth (140 and $28 \mathrm{~m}$ ). Although mean macrofaunal abundance was similar to that in the German Bight, a lower biomass (except in September in the Kattegat), and the dominance of interface feeders such as A. filiformis and the polychaetes Myriochele spp. and suspension-feeders such as Phoronis spp. indicate that sedimentation and burial of fresh organic matter is lower in these areas than in the German Bight. Thus, the communities are more dependent on lateral transport of organic matter in this area (Rosenberg 1995). In contrast to the A. filiformis community, which occurs in the Oyster Ground, microbial parameters in the Skagerrak and Kattegat were typical for depositional sites, but the microbes seemed to use different food sources (e.g. more refractory organic carbon) than the microbial community in the German Bight.

For the Dogger Bank, an area strongly affected by hydrodynamics (Kröncke \& Knust 1995), Wieking \& Kröncke $(2001,2003)$ described the Bathyporeia-Fabulina community as being dominated by interface-feeding polychaetes and sand-licking amphipods that clean off the microalgae from each sand grain (Nicolaisen \& Kanneworff 1969, Sundbäck \& Persson 1981, Herman et al. 2000, Wieking \& Kröncke 2003). The dominance of sand-licking amphipods indicate benthic primary production as described for other shallow areas (Cahoon et al. 1993, Nelson et al. 1999). Benthic primary production at the Dogger Bank is supported by sufficient nutrients (Brockmann et al. 1990, Bo Pedersen 1994) and considerable light penetration down to $40 \mathrm{~m}$ depth (Riegman et al. 1990, Nielsen et al. 1993, Jones et al. 1998). Fairly high chl a concentrations and microbial substrate preference of amino acids and a phytosugar polymer in this area (Stoeck et al. 2003) confirm the role of benthic primary production for the nutrition of benthic Dogger Bank communities. Our own (unpubl.) data comparing phytopigment concentrations of total and decanted Dogger Bank sediments have revealed that the sand fraction provides a pattern of chl $a, \operatorname{chl} c$ and fuxoxanthin concentrations characteristic for benthic microalgae, as also found by Cahoon et al. (1993) and Nelson et al. (1999). And we saw benthic microalgae adhering to the sand grains using electron microscopy.

Concerning microbes, the presence of marker PLFAs for aerobic microeukaryotes and bacteria, associated with strategies for survival during physiological stress (probably hydrodynamical and food-related) (Stoeck et al. 2002) confirms that the Dogger Bank is a hydrodynamically affected area.

The eastern North Sea is inhabited by the Fabulina fabula community (Niermann 1997, Rachor \& Nehmer unpubl. data). In the present study, the community was dominated by the small echinoid Echinocyamus pusillus in May; this species forages as a sand-licker (Ghiold 1982). As for amphipods at the Dogger Bank, this feeding mode indicates benthic primary production as an important food resource for the macrofauna. The further presence of suspension- and interface-feeding species indicates that the area is strongly affected by hydrodynamics and thus lateral transport of organic matter. Phoronids dominated the community in Sep- 
tember and were found in maximum abundances of about 45000 individuals $\mathrm{m}^{-2}$ at Stns EN2 and EN3. The baffling behaviour of the phoronids led to high mud concentrations at these stations. Hickel et al. (1989) and Niermann (1997) also found the highest abundance of phoronids in the same area. Hickel et al. (1989) and Bauerfeind et al. (1990) also measured high chl $a$ and phytoplankton carbon concentrations in the bottom water of this area indicating that the phoronids are directly favoured by the high food supply. On the other hand, the presence of phoronids may cause microbe-phoronid interactions since settling and metamorphosis of Phoronis spp. is known to be related to biofilms (Herrmann 1995).

\section{Food competition and role of hydrodynamics in food availability}

On a eutrophic shelf sea such as the North Sea food supply should not be a limiting factor. Kristensen (2000) found reduced microbial activity in surface sediments in the presence of the polychaete Nereis diversicolor. Beside direct competition for food at the surface, bioturbation enhances microbial remineralisation of organic matter and thus sediment chemistry in deeper sediment layers (Kristensen \& Blackburn 1987, Aller 1988, van Duyl \& Kop 1994, Forster et al. 1995, Osinga et al. 1996, Ziebis et al. 1996, Kristensen 2000). Sediment chemistry may influence the structure and function of microbial and macrofaunal communities.

However, our results indicate that microbial and macrofaunal communities in the depositional area of the inner German Bight seem to receive enough fresh and nitrogen-rich food to obviate any need for competition. The surplus of food not used by organisms in surface sediments is buried in deeper sediment layers, where it becomes available to subsurface-feeding macrofauna and microbes. This indicates a benthic food web structure based on sufficient food supply and low food competition.

In the other depositional areas, the Skagerrak and Kattegat, the situation is different. Macrofaunal feeding modes hint at a stronger influence of hydrodynamics, and sediment parameters and CCAs reveal a sedimentation of more refractory organic matter (TOC) that is utilised by microbial and macrofaunal communities.

In areas with stronger hydrodynamics and a low deposition of organic matter such as the Oyster Ground and the eastern North Sea, the dominance of interface- and suspension-feeders such as brittlestars and phoronids reflects the fact that in most parts of the North Sea advection (hydrodynamics) controls the availability of food (Wieking \& Kröncke 2003, Wieking \& Kröncke in press). In such areas, macrofauna, which feed in the benthic boundary layer, are essential for the transport of organic matter produced in the water column to the benthic system. Our data show that in such areas microbial communities are also dependent on macrofaunal excretion products.

On the Dogger Bank, hydrodynamics are so strong that hardly any sedimentation of organic matter takes place. Thus, food for the dominant sand-licking amphipods is derived from benthic primary production (Wieking \& Kröncke 2003). The poor correlation between microbial/macrofaunal and sediment parameters indicates that the microbial and macrofaunal communities are nutritionally independent and use different food sources, and suggests the existence of food chains similar to those under food limited conditions in the deep sea (Kröncke et al. 2000).

Acknowledgements. We thank the captain and crew of RV Senckenberg and C. Rensing, T. Jansen and other assistants who helped at sea and in the laboratory. Special thanks to G. Duineveld, NIOZ, for organising the RNA/DNA analyses. We are thankful especially to 1 of 3 anonymous referees for his very helpful comments on the manuscript. Thanks to Dominica Nichols, 1 referee and 1 editor for correcting the English. This study was financed by a grant from the Deutsche Forschungsgemeinschaft (DFG) to T. Stoeck (STO 414/1-1) and by funds of the Senckenberg Natural History Society and the MTT Agrifood Research Finland.

\section{LITERATURE CITED}

Aigner T, Reineck HE (1982) Proximality trends in modern storm sands from the Helgoland Bight (North Sea) and their implication for basin analysis. Senckenb Marit 14: $183-215$

Aller RC (1982) The effects of macrobenthos on chemical properties of marine sediment and overlying water. In: McCall PL, Tevesz MJC (eds) Animal-sediment relations. Plenum, New York, p 53-102

Aller RC (1988) Benthic fauna and biogeochemical processes in marine sediments: the role of burrow structures. SCOPE 33:301-338

Aller RC, Yingst JY (1982) Relationship between microbial distributions and the anaerobic decomposition of organic matter in surface sediments of Long Island Sound, USA. Mar Biol 56:29-42

Alongi DM, Hanson RB (1985) Effects of detritus supply on trophic relationships within experimental benthic food webs. II. Microbial responses, fate and composition of decomposing detritus. J Exp Mar Biol Ecol 88:167-182

Alongi DM, Tenore KR (1985) Effects of detritus supply on trophic relationships within experimental benthic food webs. I. Meiofauna-polychaete (Capitella capitata (Type I) Fabricius) interactions. J Exp Mar Biol Ecol 88:155-166

Andersen FØ, Kristensen E (1988) The influence of macrofauna on estuarine benthic community metabolisms: a microcosm study. Mar Biol 99:591-603

Andersen FØ, Kristensen E (1991) Effects of burrowing macrofauna on organic matter decomposition in coastal marine sediments. Symp Zool Soc 63:69-88

Andersen FØ, Kristensen E (1992) The importance of benthic macrofauna in decomposition of microalgae in a coastal 
marine sediment. Limnol Oceanogr 37:1392-1403

Anton KK, Liebezeit G, Rudolph C, Wirth H (1993) Origin, distribution and accumulation of organic carbon in the Skagerrak. Mar Geol 111:287-297

Basford DJ, Eleftheriou A, Davies M, Irion G, Soltwedel T (1993) The ICES North Sea benthos survey: the sedimentary environment. ICES J Mar Sci 50:71-80

Bauerfeind E, Hickel W, Niermann U, von Westernhagen $\mathrm{H}$ (1990) Phytoplankton biomass and potential nutrient limitation of phytoplankton development in the southeastern North Sea in spring 1985 and 1986. Neth J Sea Res 25: 131-142

Becker GA, Dick S, Dippner JW (1992) Hydrography of the German Bight. Mar Ecol Prog Ser 91:9-18

Billen G, Joiris C, Meyer-Reil L, Lindeboom H (1990) Role of bacteria in the North Sea ecosystem. Neth J Sea Res 26: 265-293

Boetius A, Lochte K (1994) Regulation of microbial enzymatic degradation of organic matter in deep-sea sediments. Mar Ecol Prog Ser 104:299-307

Boon AR, Duineveld GCA (1998) Chl a as a marker for bioturbation and carbon flux in southern and central North Sea sediments. Mar Ecol Prog Ser 162:33-43

Boon AR, Duineveld GCA, Kok A (1999) Benthic organic matter supply and metabolism at depositional and nondepositional areas in the North Sea. Estuar Coast Shelf Sci 49:747-761

Bo Pedersen F (1994) The oceanographic and biological tidal cycle succession in shallow sea fronts in the North Sea and the English Channel. Estuar Coast Shelf Sci 38:249-269

Bridges TS, Levin LA, Cabrera D, Plaia G (1994) Effects of sediment amended with sewage, algae, or hydrocarbons on growth and reproduction in two opportunistic polychaetes. J Exp Mar Biol Ecol 177:99-119

Brockmann U, Wegner G (1985) Hydrography, nutrient and chlorophyll distribution in the North Sea in February 1984. Arch FischWiss 36:27-45

Brockmann U, Laane RWPM, Postma H (1990) Cycling of nutrient elements in the North Sea. Neth J Sea Res 26: $239-264$

Cadée GC (1984) Macrobenthos and macrobenthic remains on the Oyster Ground, North Sea. Neth J Sea Res 18: 160-178

Cahoon LB, Beretich GR Jr, Thomas CJ, McDonald AM (1993) Benthic microalgal production at Stellwagen Bank, Massachusetts Bay, USA. Mar Ecol Prog Ser 102:179-185

Clarke KR, Warwick M (1994) Change in marine communities: an approach to statistical analysis and interpretation, Natural Environment Research Council, Swindon

Copella SJ, Acheson CM, Dhurjati P (1987) Isolation of highmolecular-weight nucleic acids for copy number analysis using high-performance liquid chromatography. J Chromatogr 402:189-199

Dauwe B, Middelburg JJ (1998) Amino acids and hexosamines as indicators of organic matter degradation state in North Sea sediments. Limnol Oceanogr 43:782-798

Dauwe B, Herman PMJ, Heip CHR (1998) Community structure and bioturbation potential of macrofauna at four North Sea stations with contrasting food supply. Mar Ecol Prog Ser 173:67-83

Dauwe B, Middelburg JJ, van Rijswijk P, Sinke J, Herman PMJ, Heip CHR (1999) Variations of enzymatically hydrolysable amino acids in North Sea sediments and their possible implication for the nutritional value. J Mar Res 57(1):109-134

de Haas H, van Weering TCE (1997) Recent sediment accumulation, organic carbon burial and transport in the north- eastern North Sea. Mar Geol 136:173-187

de Haas H, Boer W, van Weering TCE (1997) Recent sedimentation and organic carbon burial in a shelf sea: the North Sea. Mar Geol 144:131-146

Delafontaine MT, Bartholomä A, Flemming BW, Kurmis R (1996) Volume-specific dry POC mass in surficial intertidal sediments: a comparison between biogenic muds and adjacent sand flats. Senckenberg Marit 26:167-178

Dippner JW (1993) A frontal-resolving model for the German Bight. Contin Shelf Res 13:49-66

Dortch Q, Roberts TL, Clayton JR, Ahmed SI (1983) RNA/DNA ratios and DNA concentrations as indicators of growth rate and biomass in planktonic marine organisms. Mar Ecol Prog Ser 13:61-71

Duineveld GCA, de Wilde PAWJ, Kok A (1990) A synopsis of the macrobenthic assemblages and benthic ETS-activity in the Dutch sector of the North Sea. Neth J Sea Res 26: $125-138$

Eisma D, Kalf J (1987) Dispersal, concentration and deposition of suspended matter in the North Sea. J Geol Soc (Lond) 144:161-178

Fauchald K, Jumars PA (1979) The diet of worms: a study of polychaete feeding guilds. Oceanogr Mar Biol Annu Rev 17:193-284

Figge K (1981) Sedimentverteilung in der Deutschen Bucht. Karte Nr. 2900, Deutsches Hydrographisches Institut, Hamburg

Flemming BW, Delafontaine MT (2000) Mass physical properties of muddy intertidal sediments: some applications, misapplications and non-applications. Cont Shelf Res 20: 1179-1197

Forster S, Graf G, Kitlar J, Powilleit M (1995) Effects of bioturbation in oxic and hypoxic conditions: a microcosm experiment with a North Sea sediment community. Mar Ecol Prog Ser 116:153-161

Frantzis A, Gremare A, Vetion G (1992) Growth rates and RNA/DNA ratios in Paracentrotus lividus (Echinodermata: Echinoidea) fed on benthic macrophytes. J Exp Mar Biol Ecol 156:125-138

Frantzis A, Gremare A, Vetion G (1993) Taux de croissance et rapport ARN/ADN chez le bivalve depositivore Abra ovata norri a partir de different detritus. Oceanol Acta 16: 303-312

Frostegård Å, Bååth E, Tunlid A (1993) Phospholipid fatty acid composition, biomass and activity of microbial communities from two soil types experimentally exposed to different heavy metals. Appl Environ Microbiol 59: 3605-3617

Ghiold J (1982) Observations on the clypeasteroid Echinocyamus pusillus (O. F. Müller). J Exp Mar Biol Ecol 61:57-74

Hagmeier A (1925) Vorläufiger Bericht über die vorbereitenden Untersuchungen der Bodenfauna der Deutschen Bucht mit dem Petersen-Bodengreifer. Ber Dtsch Wiss Komm Meeresforsch NF 1:247-272

Hartmann-Schröder G (1996) Annelida, Borstenwürmer, Polychaeta. Tierwelt Dtsch 58:1-648

Hedges JI, Stern JH (1984) Carbon and nitrogen determinations of carbonate-containing solids. Limnol Oceanogr 27: 954-958

Herman PMJ, Middelburg JJ, Widdows J, Lucas CH, Heip CHR (2000) Stable isotopes as trophic tracers: combining field sampling and manipulative labelling of food resources for macrobenthos. Mar Ecol Prog Ser 204:79-92

Herrmann K (1995) Induction and regulation of metamorphosis in planktonic larvae: Phoronis mülleri (Tentaculata) as archetype. Helgol Meeresunters 49:255-281

Hickel W (1998) Temporal variability of micro- and nano- 
plankton in the German Bight in relation to hydrographic structure and nutrient changes. In: Colijn F, Tillmann U, Smayda T (eds) The temporal variability of plankton and their physico-chemical environment. Academic Press, London, p 600-609

Hickel W, Bauerfeind E, Niermann U, Westernhagen Hv (1989) Oxygen deficiency in the south-eastern North Sea: Sources and biological effects. Ber Biol Anst Helgol 4: $1-148$

Holm-Hansen O, Sutcliffe WH Jr, Sharp J (1968) Measurement of desoxyribunucleic acid in the ocean and its ecological significance. Limnol Oceanogr 13:507-514

Joint I, Pomroy A (1993) Phytoplankton biomass and production in the southern North Sea. Mar Ecol Prog Ser 99: 169-182

Jones SE, Jago CF, Bale AJ, Chapman D, Howland RJM, Jackson J (1998) Aggregation and resuspension of suspended particulate matter at a seasonally stratified site in the southern North Sea: physical and biological controls. Cont Shelf Res 18:1283-1309

Josefson AB (1998) Resource limitation in marine soft sediments - differential effects of food and space in the association between the brittle-star Amphiura filiformis and the bivalve Mysella bidentata? Hydrobiologia 375/376: 297-305

Josefson AB, Conley DJ (1997) Benthic response to a pelagic front. Mar Ecol Prog Ser 147:49-62

Josefson AB, Jensen JN, Aertebjerg G (1993) The benthos community structure anomaly in the late 1970s and early 1980 s - a result of a major food pulse? J Exp Mar Biol Ecol 172:31-45

Kemp WM (1990) The fate of benthic bacterial production. Aquat Sci 2:109-124

Kristensen E (1988) Benthic fauna and biogeochemical processes in marine sediments: microbial activities and fluxes. SCOPE 33:275-299

Kristensen E (2000) Organic matter diagenesis at the oxic/anoxic interface in coastal marine sediments, with emphasis on the role of burrowing animals. Hydrobiologia 426:1-26

Kristensen E, Blackburn TH (1987) The fate of organic carbon and nitrogen in experimental marine sediment systems: influence of bioturbation and anoxia. J Coast Res 45: 231-257

Kristensen E, Jensen MH, Andersen TK (1985) The impact of polychaete (Nereis virens Sars) burrows on nitrification and nitrate reduction in estuarine sediments. J Exp Mar Biol Ecol 85:75-91

Kristensen E, Ahmed SI, Devol AH (1995) Aerobic and anaerobic decomposition of organic matter in marine sediments: Which is fastest? Limnol Oceanogr 40(8):1430-1437

Kröncke I (1992) Macrofauna standing stock of the Dogger Bank. A comparison: III. 1950-54 versus 1985-87: A final summary. Helgol Meeresunters 46:137-169

Kröncke I, Bergfeld C (2003) North Sea benthos: a review. Senckenb Marit 33:205-268

Kröncke I, Knust R (1995) The Dogger Bank: a special ecological region in the central North Sea. Helgol Meeresunters 49:335-353

Kröncke I, Rachor E (1992) Macrofauna investigations along a transect from the inner German Bight towards the Dogger Bank. Mar Ecol Prog Ser 91:269-276

Kröncke I, Vanreusel A, Vincx M, Wollenburg J, Mackensen A, Liebezeit G, Behrends B (2000) The different benthic size compartments and their relation with sediment chemistry in the deep Eurasian Arctic Ocean. Mar Ecol Prog Ser 199:31-41
Künitzer A, Basford D, Craeymeersch JA, Dewarumez JM and 10 others (1992) The benthic infauna of the North Sea: species distribution and assemblages. ICES J Mar Sci 49: 127-143

Lechevalier (1977) Lipids in bacterial taxonomy-a taxonomists view. Crit Rev Microbiol 5:109-210

Liebezeit G (1987) Early diagenesis of carbohydrates in the marine environment. II. Composition and origin of carbohydrates in Skagerrak sediments. Org Geochem 13(1-3): 387-391

Lincoln RJ (1979) British marine Amphipoda: Gammaridea. British Museum of Natural History, London

Marsh AG, Tenore KR (1990) The role of nutrition in regulating the population dynamics of opportunistic, surface deposit feeders in a mesohaline community. Limnol Oceanogr 35:710-724

McCarthy AJ (1989) Lignocellulose-degrading Actinomycetes. FEMS Microbiol Rev 46:145-163

Meyenburg G, Liebezeit G (1993) Mineralogy and geochemistry of a core from the Skagerrak/Kattegat boundary. Mar Geol 111:337-344

Middelburg JJ, Vlug T, van der Nat FJWA (1993) Organic matter mineralization in marine systems. Global Planet Change 8:47-58

Nelson JR, Eckman JE, Robertson CY, Marinelli RL, Jahnke RA (1999) Benthic microalgal biomass and irradiance at the sea floor on the continental shelf of the South Atlantic Bight: spatial and temporal variability and storm effects. Cont Shelf Res 19:477-505

Nicolaisen W, Kanneworff E (1969) On the burrowing and feeding habits of the amphipods Bathyporeia pilosa Lindström and Bathyporeia sarsi Watkin. Ophelia 6:231-250

Nielsen TG, Lokkegard B, Richardson K, Bo Pedersen F, Hansen L (1993) Structure of plankton communities in the Dogger Bank area (North Sea) during a stratified situation. Mar Ecol Prog Ser 95:115-131

Niermann U (1997) Macrobenthos of the south-eastern North Sea during 1983-1988. Ber Biol Anst Helgol 13:1-144

Niermann U, Bauerfeind E, Hickel W, von Westernhagen H (1990) The recovery of benthos following the impact of low oxygen concentration in the German Bight. Neth J Sea Res 25:215-226

Osinga R, Kop AJ, Duineveld GCA, Prins RA, van Duyl FC (1996) Benthic mineralization rates at two locations in the southern North Sea. J Sea Res 36:181-191

Otto L, Zimmermann JTF, Furnes GK, Mork K, Saetre R, Becker G (1990) Review of the physical oceanography of the North Sea. Neth J Sea Res 26:261-283

Palojärvi A, Sharma S, Rangger A, von Lützow M, Insam H (1997) Comparison of Biolog and phospholipid fatty acid patterns to detect changes in microbial community after maize straw applications. In Insam H, Rangger A (eds) Microbial communities: functional versus structural approaches. Springer-Verlag, Berlin, p 37-48

Puls W, Heinrich H, Mayer B (1997) Suspended particulate matter budget for the German Bight. Mar Pollut Bull 34: 398-409

Ricciardi A, Bourget E (1998) Weight-to-weight conversion factors for marine benthic invertebrates. Mar Ecol Prog Ser 163:245-251

Rice DL, Rhoads DC (1989) Early diagenesis of organic matter and the nutritional value of sediment. Lecture Notes Coast Estuar Stud 31:59-97

Riegman R, Malschaert H, Colijn F (1990) Primary production of phytoplankton at a frontal zone located at the northern slope of the Dogger Bank (North Sea). Mar Biol 105: 329-336 
Rosenberg R (1995) Benthic marine fauna structured by hydrodynamic processes and food availability. Neth J Sea Res 34 (4):303-317

Rowe GT (1996) The cycling of organic matter in food limited environments. Biosyst Ecol Ser 11:233-260

Rowe GT, Deming JW (1985) The role of bacteria in the turnover of organic carbon in deep-sea sediments. J Mar Res 43:925-950

Rowe GT, Pariente V (eds) (1992) Deep-sea food chains and the global carbon cycle. NATO ASI Ser Ser C: Math Phys Sci 360

Rowe G, Sibuet M, Deming J, Khripounoff A, Tietjen J, Macko S, Theroux R (1991) Total sediment biomass and preliminary estimates of organic carbon residence time in deep-sea benthos. Mar Ecol Prog Ser 79:99-114

Rumohr H, Brey T, Ankar S (1987) A compilation of biometric conversion factors for benthic invertebrates of the Baltic Sea. Publ Baltic Mar Biol 9:1-56

Salzwedel H, Rachor E, Gerdes D (1985) Benthic macrofauna communities in the German Bight. Veröff Inst Meeresforsch Bremerhav 20:199-267

Sibuet M, Lambert CE, Chesselet R, Laubier L (1989) Density of the major size groups of benthic fauna and trophic input in deep basins of the Atlantic Ocean. J Mar Res 47: 851-867

Stoeck T, Albers BP (2000) Microbial biomass and activity in the vicinity of a mussel bed built up by the blue mussel Mytilus edulis. Helgol Mar Res 54:39-46

Stoeck T, Kröncke I (2001) Influence of particle mixing on vertical profiles of chlorophyll a and bacterial biomass in sediments of the German Bight, Oyster Ground and Dogger Bank (North Sea). Estuar Coast Shelf Sci 52:783-795

Stoeck T, Duineveld GCA, Kok A, Albers BP (1998) Extraktion und Quantifizierung von Nukleinsäuren aus Sedimenten. In: Vereinigung für Allgemeine und Angewandte Mikrobiologie (VAAM) (ed) Mikrobiologische Charakterisierung aquatischer Sedimente. Oldenburg, München, p 47-57

Stoeck T, Duineveld GCA, Kok A, Albers BP (2000) Nucleic acids and ATP to assess microial biomass and activity in a marine biosedimentary system. Mar Biol 137:1111-1123

Stoeck T, Kröncke I, Duineveld GCD, Palojärvi A (2002) Phospholipid fatty acid profiles at depositional and non-depositional sites in the North Sea. Mar Ecol Prog Ser 241:57-70

Stoeck T, Kröncke I, Garland J (2003) Functional profiles of microbial communities in southern and central North Sea sediments in relation to organic carbon input. Senckenb Marit 32:11-24

Sundbäck K, Persson LE (1981) The effect of microbenthic grazing by an amphipod, Bathyporeia pilosa, Lindström. Kiel Meeresforsch 5:573-575

Sundbäck K, Jonsson B, Nilsson P, Lindström I (1990) Impact

Editorial responsibility: Otto Kinne (Editor),

Oldendorf/Luhe, Germany of accumulating drifting macroalgae on a shallow-water sediment system: an experimental study. Mar Ecol Prog Ser 58:261-274

Tenore KR (1983) What controls the availability to animals of detritus derived from vascular plants: organic nitrogen enrichment or caloric availability? Mar Ecol Prog Ser 10: 307-309

Tenore KR, Chesney E (1985) The interaction of rate of food supply and population density upon the bioenergetics of the opportunistic polychaete, Capitella capitata (Type I). Limnol Oceanogr 30:1188-1195

ter Braak CFJ (1986) Canonical correspondence analysis: a new eigenvector technique for multivariate direct gradient analysis. Ecol 67(5):1167-1179

ter Braak CFJ, Verdonschot PFM (1995) Canonical correspondence analysis and related multivariate methods in aquatic ecology. Aquat Sci 57/3. Birkhäuser, Basel

ter Braak CJF, Smilauer P (1998) CANOCO reference manual and user's guide to Canoco for Windows. Ithaca, NY

Upton AC, Nedwell DB, Parkes RJ, Harvey SM (1993) Seasonal benthic microbial activity in the southern North Sea; oxygen uptake and sulphate reduction. Mar Ecol Prog Ser 101:273-281

van Duyl FC, Kop AJ (1994) Bacterial production in North Sea sediments: clues to seasonal and spatial variations. Mar Biol 120:323-337

van Duyl FC, van Raaphorst W, Kop AJ (1993) Benthic bacterial production and nutrient sediment-water exchange in sandy North Sea sediments. Mar Ecol Prog Ser 100:85-95

van Weering TCE, Berger GW, Okkels E (1993) Sediment transport, resuspension and accumulation rates in the northeastern Skagerrak. Mar Geol 111:269-285

Vestal JR, White DC (1989) Lipid analysis in microbial ecology. BioScience 39:535-541

Wallerstein P, Liebezeit G (1999) Determination of photosynthetic pigments. In Grasshoff $\mathrm{K}$, Kremling $\mathrm{K}$, Ehrhard $\mathrm{M}$ (eds) Methods of seawater analysis. Wiley-VCH Verlag, Weinheim, p 557-566

Wieking G, Kröncke I (2001) Decadal changes in macrofauna communities on the Dogger Bank caused by large-scale climate variability. Senckenb Marit 31:125-141

Wieking G, Kröncke I (2003) Macrofauna communities of the Dogger Bank (central North Sea) in the late 90s: Spatial distribution, species composition and trophic structure. Helgol Mar Res 57:34-46

Wieking G, Kröncke I (in press) Is benthic trophic structure affected by food quality? The Dogger Bank example. Mar Biol

Wirth H, Wiesner MG (1988) Sedimentary facies in the North Sea. Mitt Geol-Paläont Inst Univ Hamb 65:289-311

Ziebis W, Huettel M, Forster S (1996) Impact of biogenic sediment topography on oxygen fluxes in permeable seabeds. Mar Ecol Prog Ser 140:227-237

Submitted: July 22, 2003; Accepted: June 24, 2004

Proofs received from author(s): November 5, 2004 